\title{
Combinatorial pretreatment and fermentation optimization enabled a record yield on lignin bioconversion
}

Zhi-Hua Liu' ${ }^{1,2,3}$, Shangxian Xie ${ }^{1,2,3}$, Furong Lin ${ }^{1,2,3}$, Mingjie Jin ${ }^{4,5}$ and Joshua S. Yuan ${ }^{1,2,3^{*}}$

\begin{abstract}
Background: Lignin valorization has recently been considered to be an essential process for sustainable and costeffective biorefineries. Lignin represents a potential new feedstock for value-added products. Oleaginous bacteria such as Rhodococcus opacus can produce intracellular lipids from biodegradation of aromatic substrates. These lipids can be used for biofuel production, which can potentially replace petroleum-derived chemicals. However, the low reactivity of lignin produced from pretreatment and the underdeveloped fermentation technology hindered lignin bioconversion to lipids. In this study, combinatorial pretreatment with an optimized fermentation strategy was evaluated to improve lignin valorization into lipids using R. opacus PD630.
\end{abstract}

Results: As opposed to single pretreatment, combinatorial pretreatment produced a 12.8-75.6\% higher lipid concentration in fermentation using lignin as the carbon source. Gas chromatography-mass spectrometry analysis showed that combinatorial pretreatment released more aromatic monomers, which could be more readily utilized by lignin-degrading strains. Three detoxification strategies were used to remove potential inhibitors produced from pretreatment. After heating detoxification of the lignin stream, the lipid concentration further increased by 2.9-9.7\%. Different fermentation strategies were evaluated in scale-up lipid fermentation using a 2.0-I fermenter. With laccase treatment of the lignin stream produced from combinatorial pretreatment, the highest cell dry weight and lipid concentration were 10.1 and $1.83 \mathrm{~g} / \mathrm{l}$, respectively, in fed-batch fermentation, with a total soluble substrate concentration of $40 \mathrm{~g} / \mathrm{l}$. The improvement of the lipid fermentation performance may have resulted from lignin depolymerization by the combinatorial pretreatment and laccase treatment, reduced inhibition effects by fed-batch fermentation, adequate oxygen supply, and an accurate $\mathrm{pH}$ control in the fermenter.

Conclusions: Overall, these results demonstrate that combinatorial pretreatment, together with fermentation optimization, favorably improves lipid production using lignin as the carbon source. Combinatorial pretreatment integrated with fed-batch fermentation was an effective strategy to improve the bioconversion of lignin into lipids, thus facilitating lignin valorization in biorefineries.

Keywords: Lignin valorization, Lipid, Fed-batch fermentation, Combinatorial pretreatment, Detoxification, Rhodococcus opacus PD630

\section{Background}

Biorefineries have been widely studied due to energy security, economic sustainability, and environmental concerns [1-4]. The economical biorefinery industry

\footnotetext{
*Correspondence: syuan@tamu.edu

${ }^{3}$ Institute for Plant Genomics and Biotechnology, Texas A\&M University, College Station, TX 77843, USA

Full list of author information is available at the end of the article
}

depends on the utilization of the complete cell wall (carbohydrates and lignin). Carbohydrates can be effectively converted into fermentable sugars to produce biofuels. However, conventional biorefineries, including those for cellulosic ethanol, along with the pulp and paper industries generate approximately 112 million tons of lignin "waste" annually in the United States alone [5, 6]. Such lignin is usually burned for heat and electricity 
with low-value utilization [2, 7-9]. Given the accessibility of lignin, the second most abundant natural polymer on earth after cellulose, lignin valorization will not only enable new uses for value-added products, but also be an essential process for the sustainable and competitive biorefinery industry.

However, the low reactivity of lignin in lignocellulosic biomass hinders its high-value utilization. Lignin, used by plants for structure composition, water transport, and defense, is a highly complex phenylpropanoid biopolymer that is derived from three aromatic monomers ( $p$-coumaryl alcohol, coniferyl alcohol, and sinapyl alcohol) [10, 11]. Lignin monomers have various functional groups, such as methoxyl, carbonyl groups, phenolic hydroxyl, and aliphatic hydroxyl $[12,13]$. These monomers are conjugated via various bonds, mainly including $\beta-\beta, \beta-O-$ 4 -aryl ether linkages, and $\beta-5$ linkages. These properties reinforce the resistance of the lignin polymer to depolymerize using biological and chemical methods, which have hindered both its isolation and widespread application. Therefore, a promising strategy that combines effective fractionation with bioconversion technology should be developed to both facilitate and advance lignin valorization [6, 14-16].

Oleaginous microorganisms can accumulate intracellular lipids to more than $20 \%$ of their cell dry weight [17, 18]. The fatty acids of those lipids are mainly long chain ones, which have been considered to be alternative fuel precursors for a more sustainable biodiesel industry [19-21]. Recently, lignin bioconversion into lipid by oleaginous microorganisms has attracted extensive attention due to their potential to add value and improve sustainability of biorefineries [6, 22-24]. Specifically, heterotrophic bacteria, such as Rhodococcus opacus, have evolved proficient catabolic networks ( $\beta$-ketoadipate pathways) that are capable of degrading and converting lignin to produce lipids [25-27]. As shown in Fig. 1, similar to carbohydrate processing, there are four major steps of lignin bioconversion from lignocellulosic biomass: pretreatment, enzyme depolymerization, aromatic ring biodegradation, and lipid biosynthesis by microorganisms. In general, lignin polymers in lignocellulosic biomass are fractionated by pretreatment into low molecular weight lignin derivatives and then depolymerized into aromatic

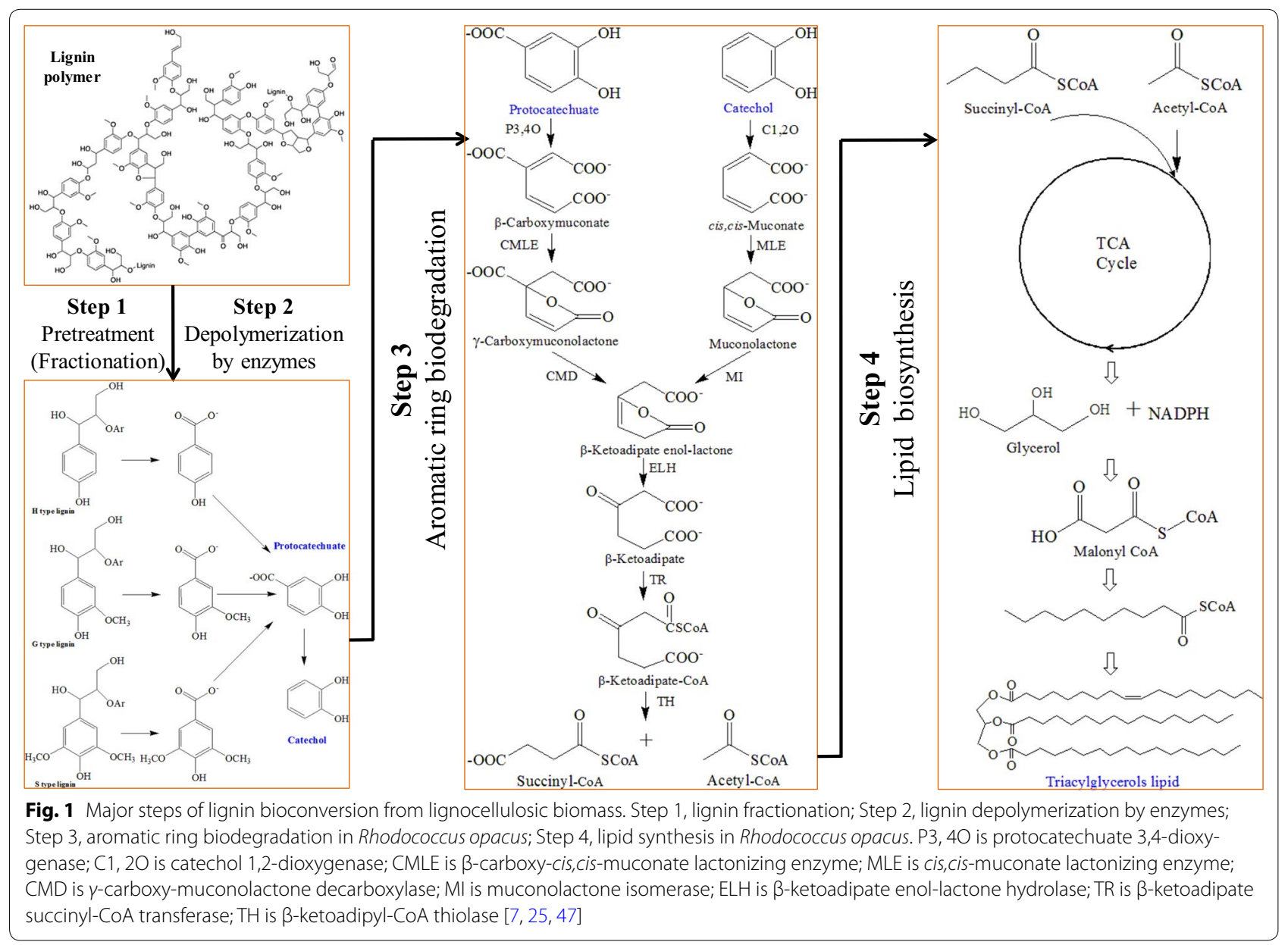


monomers by enzymes for subsequent bioconversion. However, two important factors will affect this process: (1) lignin-carbohydrate complexes hinder the lignin fractionation performance [28-31] and (2) the fractionation method alters the chemical bonds and functional groups of lignin, which determine the reactivity and bioconversion efficiency of lignin. However, the effects of different pretreatments on the bioconversion performance of lignin for lipid production are unclear.

For biodegradation and bioconversion of lignin, bacteria generally convert aromatic compounds into protocatechuate and catechol and then transfer them into $\beta$-ketoadipate, succinyl-CoA, and acetyl-CoA via $\beta$-ketoadipate pathways $[12,23,25,32]$. In the case of oleaginous bacteria, succinyl-CoA and acetyl-CoA can be consumed to produce triacylglycerols from lipid biosynthetic pathways (Fig. 1). Under normal conditions, the product yield in most microorganisms is sensitive to a number of environmental factors [33, 34]. Lipid production by Rhodococcus opacus is no exception and is determined by the strain as well as the fermentation conditions. For example, the medium composition considerably affects the growth of strains and the production of lipids. To maximize lipid production, optimization of the medium composition such as carbon source (C), nitrogen source $(\mathrm{N})$, and $\mathrm{C} / \mathrm{N}$ ratio is of great importance. In general, increases in the lipid concentration are also dependent on the substrate concentration. Unfortunately, increases in the concentration of lignin derivatives will increase the concentration of lignocellulose-derived compounds generated from pretreatment. These compounds probably inhibit strain growth and thus reduce lipid accumulation in cells. Furthermore, an increased substrate concentration may also increase the viscosity of the medium, thus affecting strain growth and process handling. In addition to optimization of pretreatment, fed-batch fermentation and a detoxification strategy may provide ways to reduce inhibition and increase the cell biomass and lipid yield [35-37]. However, these strategies have not been optimized to improve lignin bioconversion into lipids. More importantly, there is no work showing how improvement of lignin reactivity via pretreatment optimization can be integrated with fermentation optimization to improve bioconversion. To overcome these challenges and allow for high-value utilization of lignin, effective fractionation that is integrated with fermentation optimization should be developed.

The aim of this work is to improve lignin bioconversion into lipids by developing a pretreatment process and fermentation strategy. The media compositions, especially the carbon and nitrogen sources, were optimized. The combinatorial pretreatment approach was used to fractionate lignin from corn stover. The effects of combinatorial pretreatment on lignin bioconversion were studied. Fermentation modes and detoxification strategies were constantly evaluated to remove the inhibition effects of derivatives on lipid fermentation. Furthermore, different fermentation modes were conducted in scale-up lipid fermentation in a 2.0-l fermenter. This process design and optimization is crucial to improve lipid production using lignin as a carbon source by $R$. opacus PD630.

\section{Methods}

\section{Pretreatment strategies of corn stover}

Lignin was fractionated from corn stover by pretreatment using a combination of dilute sulfuric acid, liquid hot water, sodium hydroxide, and ethanol (Table 1). Pretreatment was conducted following previous procedure [38]. The pretreatment conditions used in this study were the optimal conditions determined in our lab. During Step 1 of pretreatment, $50 \mathrm{~g}$ of corn stover (dry weight, $\mathrm{dw}$ ) was loaded into a $1.0-1$ screw bottle at $10 \%(\mathrm{w} / \mathrm{w})$ solid loading using dilute sulfuric acid or liquid hot water pretreatment heating by $\mathrm{Amsco}^{\circledR}$ LG 250 Laboratory Steam Sterilizer (Steris, USA). The pretreated slurry from Step 1 was filtered by vacuum filtration to separate the solid fraction from the liquid stream. The solid fraction (loaded as described above) was then pretreated using sodium hydroxide and/or ethanol in Step 2. The liquid stream containing lignin was collected for lipid fermentation.

Table 1 Combinatorial pretreatment strategies to fractionate lignin from corn stover [38]

\begin{tabular}{|c|c|c|c|c|c|c|}
\hline \multirow[t]{2}{*}{ Case } & \multicolumn{3}{|l|}{ Step 1} & \multicolumn{3}{|l|}{ Step 2} \\
\hline & Chemicals & Conditions & Solid loading (\%) & Chemicals & Conditions & Solid loading (\%) \\
\hline 1 & $1 \% \mathrm{NaOH}$ & $120^{\circ} \mathrm{C}, 60 \mathrm{~min}$ & 10 & - & - & - \\
\hline 2 & Liquid hot water & $120^{\circ} \mathrm{C}, 30 \mathrm{~min}$ & 10 & $1 \% \mathrm{NaOH}$ & $120^{\circ} \mathrm{C}, 60 \mathrm{~min}$ & 10 \\
\hline 3 & Liquid hot water & $120^{\circ} \mathrm{C}, 30 \mathrm{~min}$ & 10 & $50 \%$ ethanol $+1 \% \mathrm{NaOH}$ & $120^{\circ} \mathrm{C}, 60 \mathrm{~min}$ & 10 \\
\hline 4 & $1 \% \mathrm{H}_{2} \mathrm{SO}_{4}$ & $120^{\circ} \mathrm{C}, 30 \mathrm{~min}$ & 10 & $1 \% \mathrm{NaOH}$ & $120^{\circ} \mathrm{C}, 60 \mathrm{~min}$ & 10 \\
\hline 5 & $1 \% \mathrm{H}_{2} \mathrm{SO}_{4}$ & $120^{\circ} \mathrm{C}, 30 \mathrm{~min}$ & 10 & $50 \%$ ethanol $+1 \% \mathrm{NaOH}$ & $120^{\circ} \mathrm{C}, 60 \mathrm{~min}$ & 10 \\
\hline
\end{tabular}

$\%$ was calculated based on the weight percent, w/w 
The process using a combination of dilute sulfuric acid or liquid hot water in Step 1 with sodium hydroxide and/or ethanol in Step 2 was named combinatorial pretreatment [38].

\section{Microorganism and seed culture preparation}

Rhodococcus opacus PD630 was purchased from the Leibniz Institute DSMZ-German Collection of Microorganisms and Cell Cultures (Braunschweig, Germany). Engineered $R$. opacus PD630_FA was used in this study to grow on minimal medium was prepared as follows. First, $1.4 \mathrm{~g}$ of $\left(\mathrm{NH}_{4}\right)_{2} \mathrm{SO}_{4}$ and $1.0 \mathrm{~g}$ of $\mathrm{MgSO}_{4} \cdot 7 \mathrm{H}_{2} \mathrm{O}$ were added into $962 \mathrm{ml}$ of $\mathrm{ddH}_{2} \mathrm{O}$, and autoclave sterilized at $121{ }^{\circ} \mathrm{C}$ for $20 \mathrm{~min}$. One milliliter $15 \mathrm{~g} / \mathrm{l}$ of $\mathrm{CaCl}_{2} \cdot 2 \mathrm{H}_{2} \mathrm{O}$, $1.0 \mathrm{ml}$ of a trace element solution, $1.0 \mathrm{ml}$ of stock A solution, and $35.2 \mathrm{ml}$ of $1.0 \mathrm{M}$ phosphate buffer were then added to the solution and finalized to $1.0 \mathrm{l}$.

The trace element solution was composed of $0.5-\mathrm{g} / \mathrm{l}$ $\mathrm{FeSO}_{4} \cdot 7 \mathrm{H}_{2} \mathrm{O}, 0.4-\mathrm{g} / \mathrm{l} \mathrm{ZnSO}{ }_{4} \cdot 7 \mathrm{H}_{2} \mathrm{O}, 0.02-\mathrm{g} / \mathrm{l} \mathrm{MnSO}_{4} \cdot \mathrm{H}_{2} \mathrm{O}$, $0.015-\mathrm{g} \mathrm{H}_{3} \mathrm{BO}_{3}, 0.01-\mathrm{g} / \mathrm{l} \mathrm{NiCl}_{2} \cdot 6 \mathrm{H}_{2} \mathrm{O}, 0.25$-g/l EDTA, $0.05-\mathrm{g} / \mathrm{l} \mathrm{CoCl}{ }_{2} \cdot 6 \mathrm{H}_{2} \mathrm{O}$, and $0.005-\mathrm{g} / 1 \mathrm{CuCl}_{2} \cdot 2 \mathrm{H}_{2} \mathrm{O}$. Stock A solution was composed of $2.0-\mathrm{g} / 1 \mathrm{NaMoO}_{2} \cdot 2 \mathrm{H}_{2} \mathrm{O}$ and 5.0-g/l FeNa-EDTA.

A single colony of $R$. opacus PD630 was inoculated in $10 \mathrm{ml}$ of Tryptic Soy Broth (TSB) medium at $28{ }^{\circ} \mathrm{C}$ for approximately $12-15$ h. $R$ opacus PD630 was then inoculated in $100 \mathrm{ml}$ of secondary seed medium (TSB) at $28^{\circ} \mathrm{C}$ with a shaking speed of $200 \mathrm{rpm}$ for approximately $24 \mathrm{~h}$ to an $\mathrm{OD}_{600} 4.0$.

\section{Lipid fermentation of the lignin stream from each pretreatment}

Lipid fermentation, using lignin from each pretreatment as the carbon source, was carried out. The liquid stream containing lignin derivatives was adjusted to $\mathrm{pH} 7.0$ by $1.0 \mathrm{M} \mathrm{HCl}$ and then sterilized at $121^{\circ} \mathrm{C}$ for $15 \mathrm{~min}$. For medium preparation, the liquid stream was dissolved to a particular soluble substrate concentration (SSC) by $\mathrm{dd}_{2} \mathrm{O}$ and transferred into a 250-ml Erlenmeyer flask with a working volume of $100 \mathrm{ml}$. The medium consisted of $0.1 \mathrm{ml}$ of $15-\mathrm{g} / \mathrm{l} \mathrm{CaCl} \cdot 2 \mathrm{H}_{2} \mathrm{O}, 0.1 \mathrm{ml}$ of a trace-element solution, $0.1 \mathrm{ml}$ of stock A solution, and $3.52 \mathrm{ml}$ of $1.0 \mathrm{M}$ phosphate buffer. $R$. opacus PD630 cell pellets, which were used for inoculation, were collected by centrifuging the seed culture at $5000 \mathrm{rpm}$ for $10 \mathrm{~min}$. Fermentation in 250-ml Erlenmeyer flasks was conducted at $\mathrm{pH} 7.0$, $28{ }^{\circ} \mathrm{C}$, and $200 \mathrm{rpm}$ for $96 \mathrm{~h}$. The scale-up fermentation was conducted in a 2.0-1 fermenter with working volume of $1.0 \mathrm{l}$ at pH 7.0, $28{ }^{\circ} \mathrm{C}, 60 \% \mathrm{pO}_{2}$, and $200 \mathrm{rpm}$ for $96 \mathrm{~h}$. For fed-batch mode, lipid fermentation in cycle 1 was conducted at $\mathrm{pH} 7.0,28{ }^{\circ} \mathrm{C}$, and $200 \mathrm{rpm}$ for $96 \mathrm{~h}$. After cycle 1 , the cell biomass was collected by centrifugation at $5000 \mathrm{rpm}$ for $10 \mathrm{~min}$ and reused in cycle 2 by feeding a new lignin medium. Tables 2 and 3 show the lipid fermentation strategies in 250-ml Erlenmeyer flasks and the 2.0-l fermenter, respectively.

\section{Detoxification of lignin stream}

To study the effects of detoxification on lipid fermentation, detoxification of the lignin stream using heating $(\mathrm{H})$, activated carbon $(\mathrm{AC})$, and gas stripping $(\mathrm{G})$ was employed. For heating detoxification, the liquid stream was loaded into a $500-\mathrm{ml}$ round-bottom reaction flask and heated in a water bath at $90^{\circ} \mathrm{C}$ for $1 \mathrm{~h}$. For activated carbon, $5 \%(\mathrm{w} / \mathrm{v})$ activated carbon was added into the lignin stream in a 500-ml flask and shaken at $200 \mathrm{rpm}$ for $12 \mathrm{~h}$ at room temperature. After detoxification, activated carbon was removed by vacuum filtration using a $0.2-\mu \mathrm{m}$ filter membrane. For gas stripping, the lignin stream was added in a 500-ml flask, and the air was put into the bottom of the flask by a vessel with a distributor to perform stripping for $3 \mathrm{~h}$.

\section{Laccase treatment of the lignin stream}

To further depolymerize lignin, the lignin stream produced from the pretreatment was treated with laccase

Table 2 Effects of inoculation OD, nitrogen source, soluble substrate, and fed-batch mode on the lipid fermentation of lignin stream by Rhodococcus opacus PD630

\begin{tabular}{|c|c|c|c|c|}
\hline Parameters & Effects of OD & Effects of nitrogen source & $\begin{array}{l}\text { Effects of soluble } \\
\text { substrates }\end{array}$ & Effects of fermentation mode \\
\hline Inoculum density (OD) & $0.5,1.0,4.0,8.0$ & 1.0 & 1.0 & 1.0 \\
\hline$\left(\mathrm{NH}_{4}\right)_{2} \mathrm{SO}_{4}(\mathrm{~g} / \mathrm{l})$ & 1.4 & $0,0.7,1.4,2.1,2.8$ & 1.4 & 1.4 \\
\hline Soluble substrate (g/l) & 15 & 15 & $7.5,15,30,45$ & 45 \\
\hline \multirow[t]{3}{*}{ Fermentation mode } & Batch & Batch & Batch & Batch: $45 \mathrm{~g} / \mathrm{l}(0 \mathrm{~h})$ \\
\hline & & & & $\begin{array}{l}\text { Fed-batch } 1: 15 \mathrm{~g} / \mathrm{l} \\
\quad(0 \mathrm{~h})+30 \mathrm{~g} / \mathrm{l}(72 \mathrm{~h})\end{array}$ \\
\hline & & & & $\begin{array}{l}\text { Fed-batch } 2: 15 \mathrm{~g} / \mathrm{l} \\
\quad(0 \mathrm{~h})+15 \mathrm{~g} / \mathrm{l}(72 \mathrm{~h})+15 \mathrm{~g} / \mathrm{l} \\
(144 \mathrm{~h})\end{array}$ \\
\hline
\end{tabular}


Table 3 Scale-up lipid fermentation strategies of lignin stream by engineered Rhodococcus opacus PD630_FA in a 2.0-I fermenter

\begin{tabular}{|c|c|c|c|c|c|c|c|}
\hline Experiment no. & Substrate & $\begin{array}{l}\text { Laccase } \\
\text { treated }\end{array}$ & $\begin{array}{l}\text { Fermentation } \\
\text { mode }\end{array}$ & Initial OD & $\mathrm{SSC}(\mathrm{g} / \mathrm{l})$ & $\begin{array}{l}\text { Total fermentation } \\
\text { time }(\mathrm{h})\end{array}$ & $\begin{array}{l}\text { Nitrogen } \\
\text { source }(g / l)\end{array}$ \\
\hline 1 & Lignin 1 & No & Batch & 1.0 & 10 at $0 \mathrm{~h}$ & 96 & 1.4 \\
\hline 2 & Lignin 1 & No & Batch & 10 & 40 at $0 \mathrm{~h}$ & 96 & 1.4 \\
\hline 3 & Lignin 1 & No & Fed-batch & 10 & 20 at $0 \mathrm{~h}+20$ at $72 \mathrm{~h}$ & 168 & 1.4 \\
\hline 4 & Lignin 4 & No & Batch & 1.0 & 10 at $0 \mathrm{~h}$ & 96 & 1.4 \\
\hline 5 & Lignin 4 & No & Fed-batch & 5.0 & 20 at $0 \mathrm{~h}+20$ at $72 \mathrm{~h}$ & 168 & 1.4 \\
\hline 6 & Lignin 4 & Yes & Fed-batch & 5.0 & 20 at $0 h+20$ at $72 h$ & 168 & 1.4 \\
\hline
\end{tabular}

Lignins 1 and 4 represent the lignin substrate fractionated by pretreatment Cases 1 and 4, as described in Table 1, respectively

SSC soluble substrate concentration

from trametes versicolor (Sigma-Aldrich, USA). Laccase treatment of lignin was conducted at a temperature of $50{ }^{\circ} \mathrm{C}$ and agitation of $200 \mathrm{rpm}$ for $48 \mathrm{~h}$ in a $1.0 \mathrm{M}$ phosphate buffer ( $\mathrm{pH} 7.0)$ inside a 1-1 flask with a breathable sealing film. 1-hydroxybenzotriazole hydrate (HBT) (Sigma-Aldrich, USA) was used as the mediator. Laccase loading of $15-\mathrm{mg} / \mathrm{g}$ substrate and a ratio 3:5 of laccase and HBT were used.

\section{Measurement of growth cell biomass and lipid concentration}

After fermentation, 100-ml fermentation broth was centrifuged at $5000 \mathrm{rpm}$ for $10 \mathrm{~min}$. The cell pellets were washed in physiological salt solution and then freezedried by lyophilizer for $24 \mathrm{~h}$. Cell dry weight (CDW) was recorded to trace cell growth. The supernatant was collected for analyzing soluble substrate concentration and lignin weight loss.

For lipid concentration analysis, the freeze-dried cell pellet was suspended with $20-\mathrm{ml}$ menthol and mixed well. After incubating in $65{ }^{\circ} \mathrm{C}$ water bath for $30 \mathrm{~min}$, $1.0-\mathrm{ml} 10 \mathrm{~N} \mathrm{NaOH}$ was added and the solution was incubated at $65{ }^{\circ} \mathrm{C}$ for $2 \mathrm{~h}$. After that, $1.0-\mathrm{ml} 98 \%(\mathrm{w} / \mathrm{w})$ $\mathrm{H}_{2} \mathrm{SO}_{4}$ was slowly added, and the solution was then incubated in $65{ }^{\circ} \mathrm{C}$ water bath for another $2 \mathrm{~h}$. The solution was cooled down to room temperature, and $8.0-\mathrm{ml}$ hexane was added. The mixture was vigorously shaken for $5 \mathrm{~min}$ and then centrifuged at $4000 \mathrm{rpm}$ for $10 \mathrm{~min}$. The top hexane layer was transferred into a labeled and preweighted glass vial (weight recorded as $W_{1}$ ). An additional 8-ml hexane was added and vigorously shaken for $5 \mathrm{~min}$, and then centrifuged at $4000 \mathrm{rpm}$ for $10 \mathrm{~min}$. The top hexane layer was again transferred into the previous glass vials. The hexane glass vials were dried to constant weight (weight recorded as $W_{2}$ ). The lipid content in cell biomass was calculated as follows:

$$
\text { Lipid content }(\mathrm{g} / \mathrm{g})=\left(W_{2}-W_{1}\right) / M_{\text {cell dry weight }}
$$

where $M_{\text {cell dry weight }}$ is the weight of freeze-dried cell biomass.

\section{Derivative analysis by gas chromatography-mass spectrometry (GC-MS)}

Lignin stream samples were centrifuged at $10,000 \mathrm{~g}$ for 10 min. Supernatant was acidified to $\mathrm{pH} 0.5-1.0$ with concentrated $\mathrm{HCl}$. 3.0-ml acidified supernatant was mixed with $1.0-\mathrm{ml}$ butanedioic acid- $d_{6}$ as the internal standard, and then extracted with three volumes of methyl tert-butyl ether (MTBE) at $4500 \mathrm{rpm}$ for $30 \mathrm{~min}$. The organic layer was collected and dried under a stream of nitrogen gas. 5.0-ml MTBE was added to dissolve the sample. The sample was then filtered by $0.22-\mu \mathrm{m}$ filter membrane for $\mathrm{GC}-\mathrm{MS}$ analysis.

GC-MS was performed on GCMS-QP2010SE (Shimadzu Scientific Instruments, Inc.) using a Shimadzu SH-Rxi-5Sil column $(30 \mathrm{~m} \times 250 \mu \mathrm{m} \times 0.25 \mu \mathrm{m})$. An aliquot of $1 \mu \mathrm{l}$ of the eluted sample was analyzed using helium as a carrier gas at a flow rate of $1.0 \mathrm{ml} / \mathrm{min}$. The temperature profile of the GC method was $3 \mathrm{~min}$ at $50{ }^{\circ} \mathrm{C}$, and then, it was increased to $290{ }^{\circ} \mathrm{C}$ at $8{ }^{\circ} \mathrm{C} / \mathrm{min}$. Ions were generated by a $70-\mathrm{eV}$ electron beam at an ionization current of $40 \mu \mathrm{A}$. Mass spectral peak identification and quantification were performed using the GCMS solution software Ver. 2.6. The height of each acquired peak was normalized against that of internal standard for further data processing.

\section{Analysis methods}

The sugars were analyzed by Ultimate 3000 HPLC System (Thermo Scientific, USA) equipped with an Aminex HPX-87P carbohydrate analysis column (Bio-Rad Laboratories, $\mathrm{CA}$ ) and a refractive index detector using HPLC grade water as the mobile phase at a flow rate of $0.6 \mathrm{ml} /$ min. SSC of the lignin stream was determined by the dry weight method using a $105^{\circ} \mathrm{C}$ oven. Lignin concentration was analyzed following the Laboratory Analysis Protocol 
(LAP) of the National Renewable Energy Laboratory (NREL), Golden, CO, USA. Error bars in the tables and figures represented the standard deviation of the replicates. For all significance tests, a student $t$ test was used requiring a probability $p<0.05$ to be significant.

\section{Results and discussion}

Lipid fermentation optimization using lignin as the carbon source

Lignin valorization enhanced the overall biorefinery competitiveness, since lignin can be used as a potential feedstock to produce high-value products such as microbial lipids $[6,15]$. Alkaline fractionated lignin (e.g., $\mathrm{NaOH}$ ) is a potential carbon source that is utilized by Oleaginous $R$. opacus PD630 for lipid production due to its low molecular weight and high activity $[15,19]$. In general, substrate consumption and the target product yield depend on the fermentation conditions. Thus, the effects of the fermentation parameters on lipid fermentation, including inoculum density (OD) and nitrogen source, were optimized (Figs. 2, 3).

Inoculum density is one of the most important factors that affects fermentation performance [39, 40]. A high inoculum density should certainly be conducive to initiating fermentation and increasing the product yield. However, a high inoculum density requires more substrates for the seed culture, which increases the capital cost of fermentation. The effects of the inoculum density on lipid fermentation of the lignin stream produced from $\mathrm{NaOH}$ pretreatment were recorded. As shown in Fig. 2a, the cell dry weight increased from 2.11 to $3.86 \mathrm{~g} / \mathrm{l}$ when the inoculum OD increased from 0.2 to 8.0. These results suggested that a high inoculum OD led to a higher cell dry weight. One possible reason for these results is that the lignin stream produced from $\mathrm{NaOH}$ pretreatment contains various degraded products, such as acids, furans, and aromatic compounds, that are generated from carbohydrates, lignin, and other compositions in the lignocellulosic biomass $[13,35]$. Some of these compounds may exhibit inhibition effects on $R$. opacus PD630. A high inoculum density should improve the tolerability of $R$. opacus PD630 to these inhibitors and thus increase the cell biomass. Another possible reason for these results is that a higher inoculum density itself should contribute to a higher cell biomass at the end of fermentation. Notably, the cell dry weight only increased by $25.4 \%$, while the SSC increased from 15 to $30 \mathrm{~g} / \mathrm{l}$ at OD4.0 (Fig. 2a). The lipid concentration increased from 0.25 to $0.53 \mathrm{~g} / \mathrm{l}$ with the increase of the inoculum density. Unfortunately, the lipid concentration decreased by $12.8 \%$ when the SSC increased from 15 to $30 \mathrm{~g} / \mathrm{l}$ at OD4.0. It is possible that SSC increases led to increases of the inhibitors, which in turn reduced the fermentable strain growth and thus lipid accumulation.

The lipid content increased from 0.12 - to $0.14-\mathrm{g} / \mathrm{g}$ dried cell with the increase of the inoculum density, while the lipid yield increased from $0.10-$ to $0.19 \mathrm{-g} / \mathrm{g}$ lignin (Fig. 2b). These results suggested that the high inoculum OD improved both the lipid content and lipid yield. A previous study reported that Rhodococci can convert ethanol organosolv lignin (EOL) and ultrasonicated EOL to lipids and that the highest lipid content is $4.08 \%$ of the dried cell [41]. These results demonstrated that $\mathrm{NaOH}$ fractionated lignin is a suitable substrate for lipid production. Compared with that at 15-g/l SSC, the lipid content and yield were only 0.09 -g/g dried cell and 0.093$\mathrm{g} / \mathrm{g}$ lignin at $30-\mathrm{g} / \mathrm{l} \mathrm{SSC}$, respectively, which decreased by 30.4 and $41.6 \%$. These results implied that the high SSC reduced the lipid content and lipid yield. The lignin concentration, at the end of fermentation, decreased with the increase of the inoculum density (Fig. 2c). The lignin weight loss was $41-49 \%$ at $15-\mathrm{g} / \mathrm{l} \mathrm{SSC}$, while only $25 \%$ at $30-\mathrm{g} / \mathrm{l}$ SSC at OD4.0. The lignin consumption results supported the cell dry weight and lipid concentration findings. All of these results showed that a high inoculum density led to a high lipid fermentation performance. In summary, because of the high cost of the seed preparation due to using a high inoculum density, OD1.0 was used as the inoculum density for fermentation optimization.

Lipid accumulation in oleaginous microorganisms depends on the excess carbon source and a limited nitrogen source in the medium [42, 43]. The oleaginous potential was critically affected by the nitrogen source or carbon-to-nitrogen ratio [44-46]. The results showed that, similar to its effect on many other oleaginous species, the nitrogen concentration plays a key role in lipid accumulation of R. opacus PD630 (Fig. 3). Under 15-g/l SSC and OD1.0, the cell dry weight sharply increased from 1.2 to $2.95 \mathrm{~g} / \mathrm{l}$ when the nitrogen source increased from 0 to $2.1 \mathrm{~g} / \mathrm{l}$. The cell dry weight then decreased to $2.36 \mathrm{~g} / \mathrm{l}$ with a $2.8 \mathrm{-g} / \mathrm{l}$ nitrogen source (Fig. 3a). The lipid concentration increased from 0.24 to $0.33 \mathrm{~g} / \mathrm{l}$ when the nitrogen source increased from 0 to $2.1 \mathrm{~g} / \mathrm{l}$. These results showed that nitrogen sources of 1.4 and $2.1 \mathrm{~g} / \mathrm{l}$ almost produced the highest cell dry weight and lipid concentration. These results suggested that the nitrogen source should affect both the cell growth and lipid concentration. The previous work showed that R. opacus DSM 1069 and PD630 can convert the lignin model compounds into lipids under a $\mathrm{C} / \mathrm{N}$ ratio of 5:1 to 10:1 [47]. In addition, a previous study also reported that both carbon and nitrogen sources have a significant effect on cell growth and microbial lipid accumulation [48]. Interestingly, 

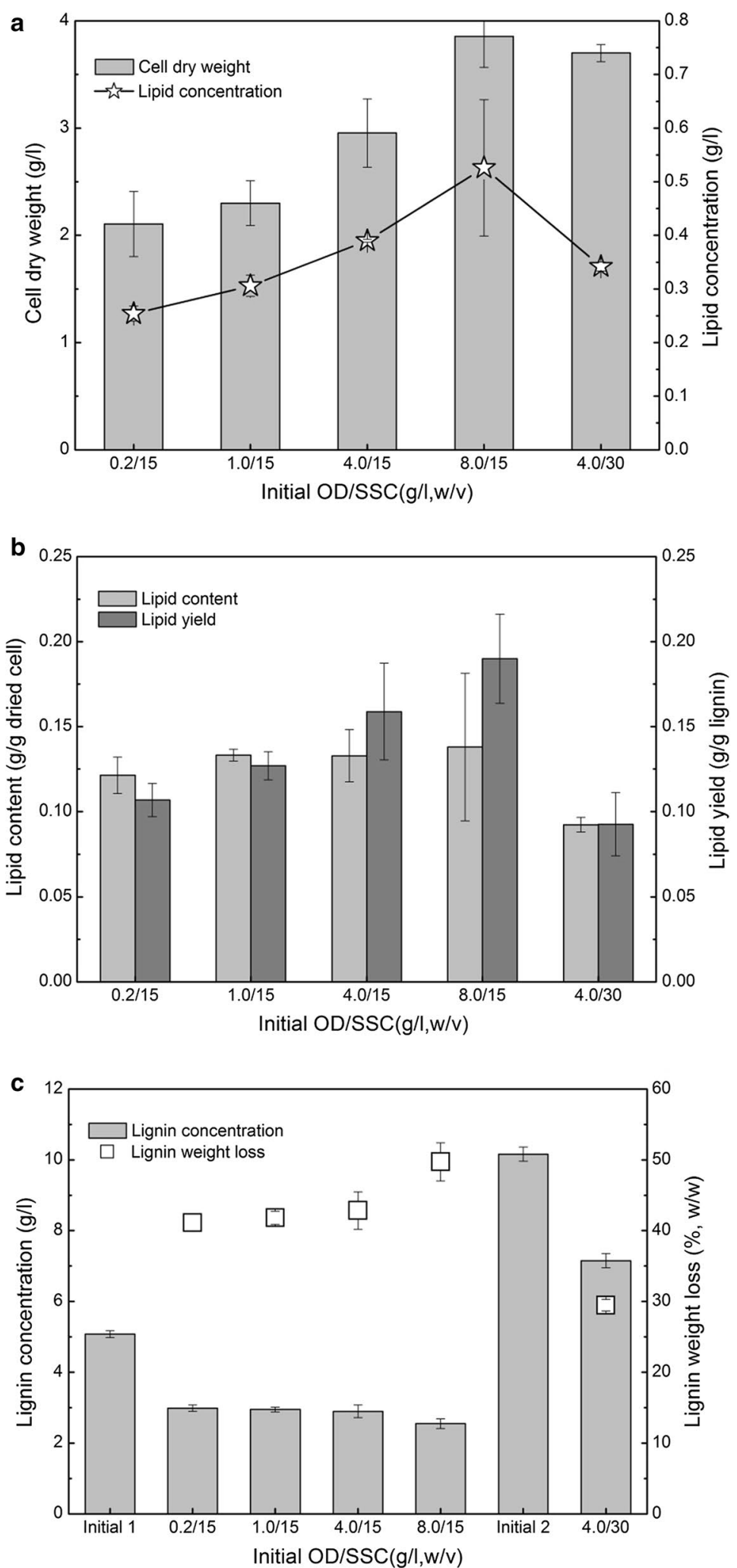

Fig. 2 Effects of inoculum OD on the lipid fermentation performance of lignin by $R$. opacus PD630. a cell dry weight and lipid concentration. $\mathbf{b}$ lipid content and yield. c lignin concentration and weight loss. Fermentation conditions: 1.4-g/l $\left(\mathrm{NH}_{4}\right)_{2} \mathrm{SO}_{4}, \mathrm{pH} 7.0,30^{\circ} \mathrm{C}, 200 \mathrm{rpm}$, and $96 \mathrm{~h}$. SSC is soluble substrate concentration. Initial 1 the initial lignin concentration at 15-g/I SSC, Initial 2 the initial lignin concentration at 30-g/l SSC 

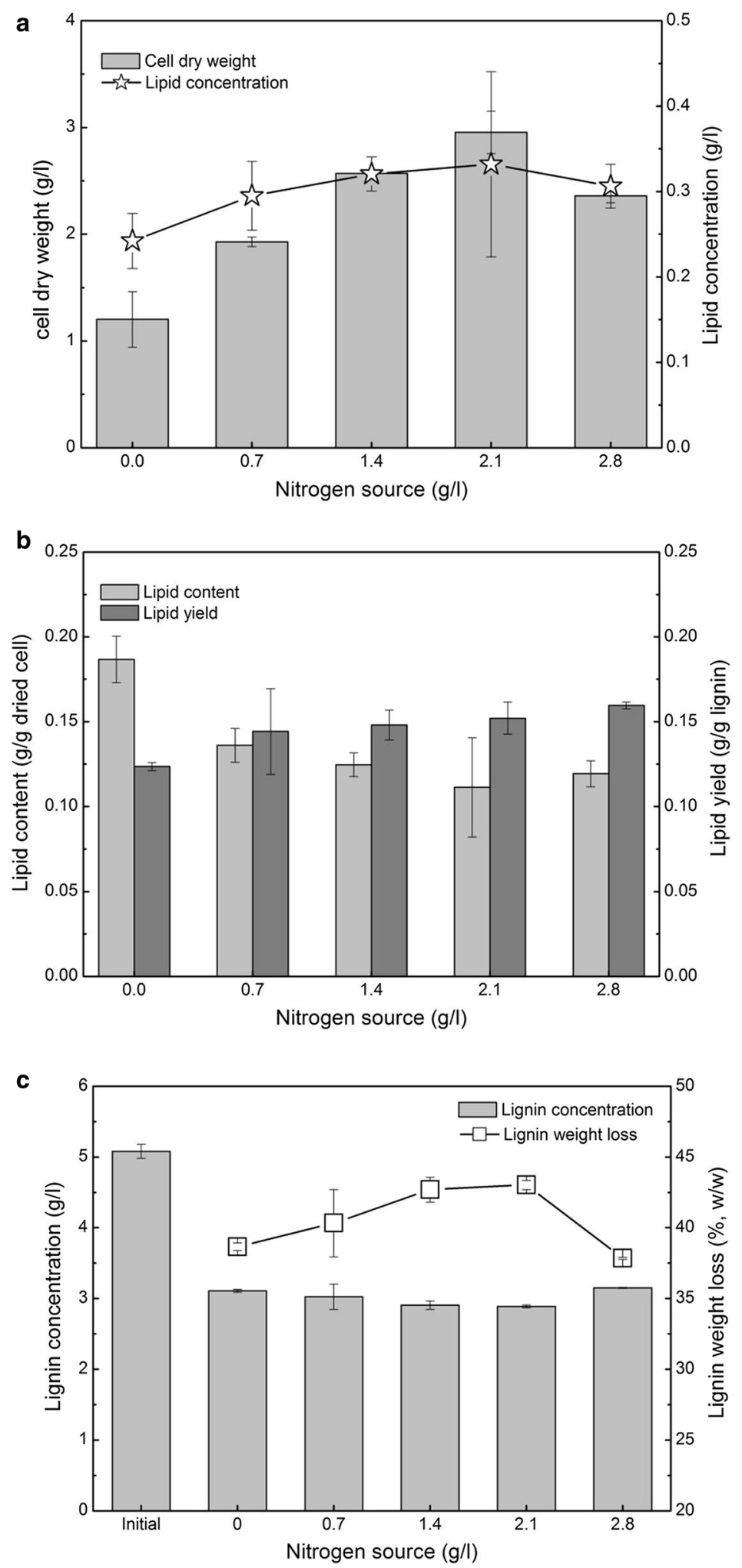

Fig. 3 Effects of nitrogen source on the lipid fermentation performance of lignin by R. opacus PD630. a cell dry weight and lipid concentration. $\mathbf{b}$ lipid content and yield. $\mathbf{c}$ lignin concentration and weight loss. Fermentation conditions: $15-\mathrm{g} / \mathrm{ISSC}, \mathrm{OD} 1.0, \mathrm{pH} 7.0,30^{\circ} \mathrm{C}, 200 \mathrm{rpm}$, and $96 \mathrm{~h}$. SSC is soluble substrate concentration. Initial the initial lignin concentration 
the lipid content decreased from 0.19- to 0.11-g/l dried cell with the nitrogen source increases from 0 to $2.1 \mathrm{~g} / \mathrm{l}$, while the lipid yield increased from $0.12-$ to $0.16-\mathrm{g} / \mathrm{l}$ lignin (Fig. 3b). These results suggested that a high nitrogen source slightly increases the lipid yield, but it obviously decreases the lipid content in R. opacus PD630. An adequate nitrogen source is helpful for the growth of the cell biomass, but adverse to the accumulation of lipids. A high lipid content in the cell is helpful for improving the lipid extraction efficiency. The lignin weight loss was highest with a nitrogen source of 1.4 and $2.1 \mathrm{~g} / \mathrm{l}$. The lignin concentration and weight loss trends supported the above results. These results implied that $R$. opacus PD630 consumed more lignin substrate with a high nitrogen source to produce a higher cell-dried weight and lipid concentration. However, the high nitrogen source decreased the lipid content. Considering the nitrogen source usage, a 1.4- $\mathrm{g} / \mathrm{l}$ nitrogen source was chosen as the optimal concentration.

\section{Enhancive lipid concentration with increased lignin concentration}

A high substrate concentration is usually needed to produce a high product concentration, which is helpful to reduce the separation cost. However, as mentioned, a high SSC in the medium contains high concentrations of degradation products and reduces strain growth due to the inhibition effect and rheology behavior change $[49,50]$. The effects of the SSC on lipid production were investigated (Fig. 4). The results showed that with the SSC increasing from 7.5 to $45 \mathrm{~g} / \mathrm{l}$, the cell dry weight significantly increased from 1.9 to $4.5 \mathrm{~g} / \mathrm{l}$ (Fig. 4a). The lipid concentration at $15-\mathrm{g} / \mathrm{l}$ SSC was 1.24 times higher than that at 7.5-g/l SSC; however, it hardly changed with a further increase of the SSC. These results suggested that a high SSC increased the cell dry weight, but hardly increased the lipid concentration. Interestingly, the cell dry weight and lipid concentration at OD 4.0 and $30-\mathrm{g} / \mathrm{l}$ SSC increased by 14.2 and $9.7 \%$, respectively, compared to those at OD1.0. These results implied that a high inoculum density can increase the lipid concentration at a high SSC.

Figure $4 \mathrm{~b}$ shows that the lipid content decreased from $0.14-$ to $0.07-\mathrm{g} / \mathrm{g}$ dried cell with the SSC increasing from 7.5 to $45 \mathrm{~g} / \mathrm{l}$, while the lipid yield decreased from 0.19 - to $0.06-\mathrm{g} / \mathrm{g}$ lignin. The results implied that a high SSC produced a low lipid content and yield. Interestingly, the lipid content at OD4.0 was approximate to that with OD1.0 at $30-\mathrm{g} / \mathrm{l} \mathrm{SSC}$, but the lipid yield with OD4.0 was $6.3 \%$ higher than that with OD1.0. Results suggested that a high inoculum density produced a high lipid yield at a high SSC. Figure 4c shows that the lignin weight loss decreased from 46.3 to $27.9 \%$ with the SSC increasing from 7.5 to $45 \mathrm{~g} / \mathrm{l}$, which supported the results of the cell dry weight, lipid concentration, and lipid yield. Overall, the high SSC increased the cell dry weight and lipid concentration, but produced a low lipid content and lipid yield. There were no explanations for this phenomenon in the previous studies. The possible reason for this phenomenon was that a high SSC contains high concentrations of water extractives, ash, degradation products, and polymer segments generated from carbohydrates and lignin during pretreatment. These compounds may reduce the growth of $R$. opacus due to physical absorption and chemical inhibition effects. In addition, medium with a high SSC contains high salt concentrations that were introduced during pretreatment, which also decrease the lipid fermentation performance $[13,51]$. To facilitate lipid production at a high SSC, effective strategies that eliminate these effects should be adopted.

\section{Improved lipid concentration by fed-batch fermentation}

Fed-batch fermentation is an operational technique in biotechnological processes, and can significantly reduce the inhibition effects of substrates and increase the cell concentration. The batch and fed-batch fermentation strategies by $R$. opacus PD630 were compared at a total SSC of $45 \mathrm{~g} / \mathrm{l}$ (Table 2). Figure 5a shows that the cell dry weight in fed-batch fermentation modes 1 and 2 was 5.0 and $13.5 \%$ higher than those in the batch fermentation mode, respectively. The lipid concentrations in fedbatch fermentation modes 1 and 2 were 0.44 and $0.58 \mathrm{~g} / \mathrm{l}$, respectively, which were 1.42 and 1.9 times than those in the batch fermentation mode. Fed-batch fermentation, especially mode 2 , increased the cell dry weight and lipid concentration at a high SSC compared to the batch fermentation mode.

Figure $5 \mathrm{~b}$ shows that the lipid contents in the fed-batch fermentation modes 1 and 2 were 1.4 and 1.7 times those in the batch fermentation mode, respectively, while the lipid yields were 1.3 and 1.5 times those in the batch fermentation mode. These results showed that fed-batch fermentation mode 2 noticeably increased the lipid content and yield at a high SSC compared to the batch fermentation mode. Figure $5 \mathrm{c}$ shows that the lignin weight loss was only $28 \%$ for the batch fermentation mode. However, it reached 39.3 and $43.6 \%$ for fed-batch fermentation modes 1 and 2, respectively. These results prove that the fed-batch fermentation mode facilitates lipid production at a high SSC. It was deduced that the fed-batch fermentation mode may weaken the inhibitory effects by reducing the degradation product concentration, thus facilitating lipid fermentation. 

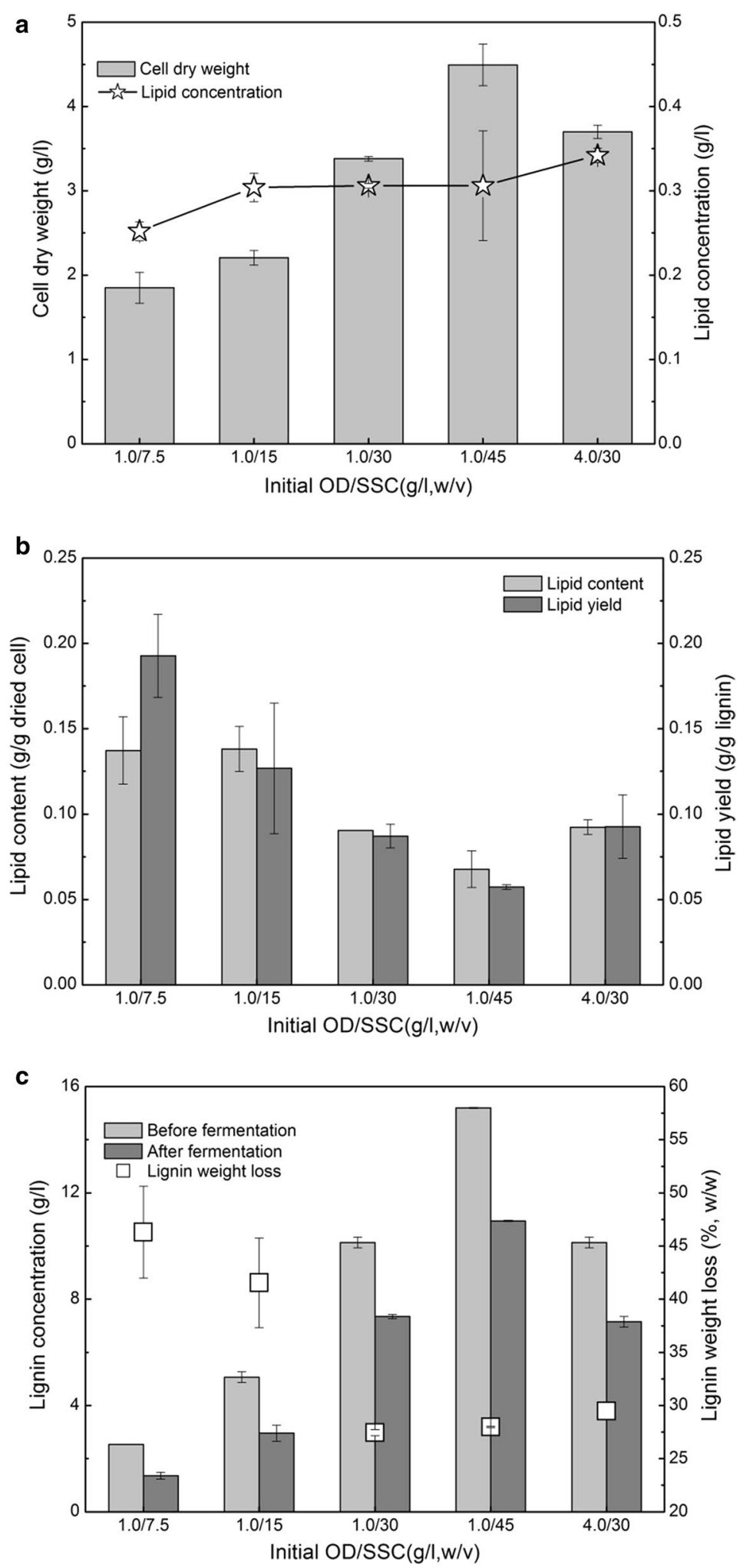

Fig. 4 Effects of soluble substrate concentration (SSC) on the lipid fermentation performance of lignin by R. opacus PD630. a cell dry weight and lipid concentration. $\mathbf{b}$ lipid content and yield. $\mathbf{c}$ lignin concentration and weight loss. Fermentation conditions: 1.4-g/l $\left(\mathrm{NH}_{4}\right)_{2} \mathrm{SO}_{4}, \mathrm{pH} 7.0,30^{\circ} \mathrm{C}$, $200 \mathrm{rpm}$, and $96 \mathrm{~h}$. SSC soluble substrate concentration 

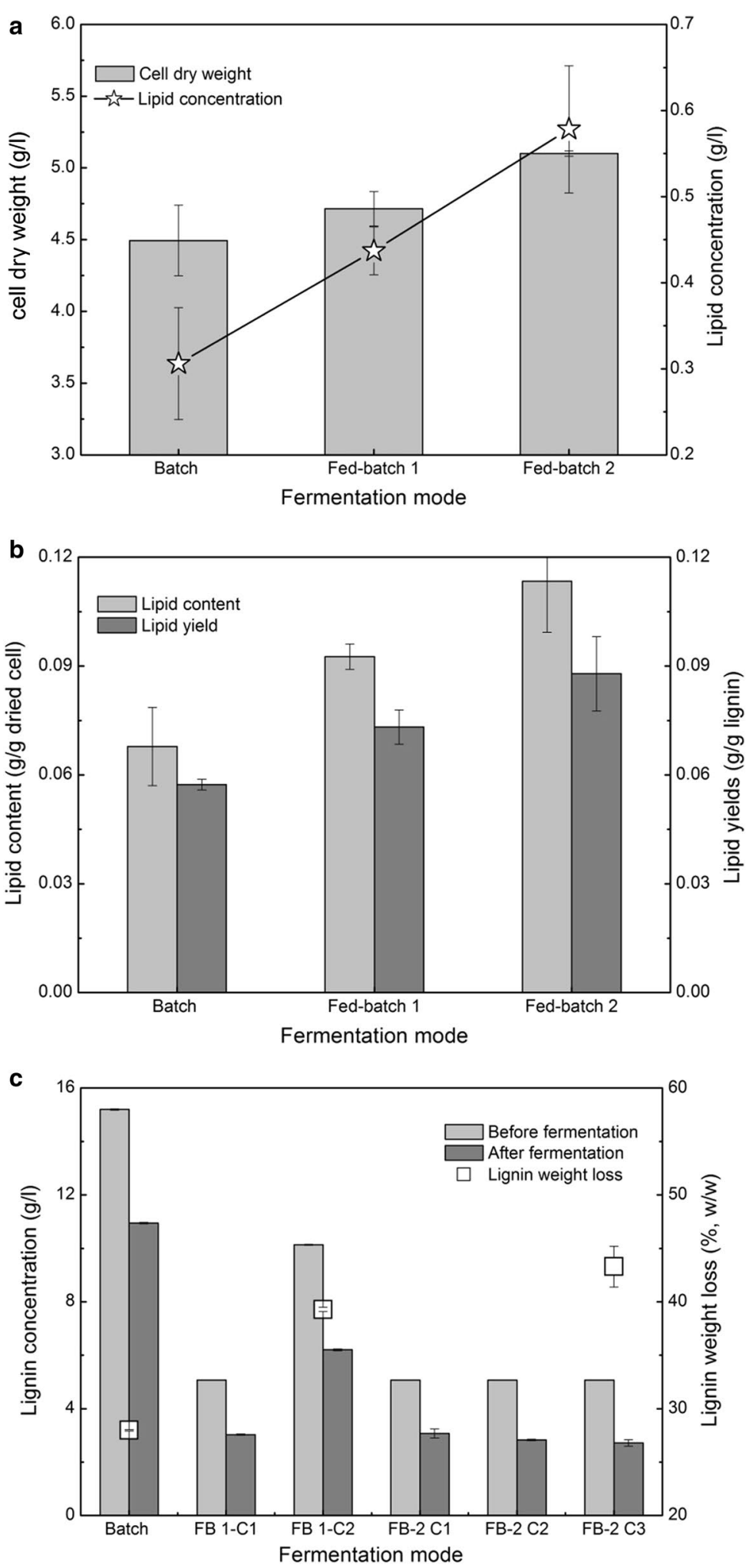

Fig. 5 Effects of fed-batch mode on the lipid fermentation performance of lignin by R. opacus PD630. a cell dry weight and lipid concentration. b lipid content and yield. c lignin concentration and weight loss. Fermentation conditions: OD1.0, 1.4-g/l $\left(\mathrm{NH}_{4}\right)_{2} \mathrm{SO}_{4}, \mathrm{pH} 7.0,30^{\circ} \mathrm{C}$, and $200 \mathrm{rpm}$. FB 1-C1 fed-batch mode 1 cycle 1, FB 2-C1 fed-batch mode 2 cycle 1 


\section{Combinatorial pretreatment improving lipid production from lignin}

Lignin reactivity is closely related to various linkages and functional groups, which determine the lignin-based product yield in the bioconversion process. Fractionation technologies can significantly modify the lignin structure as well as change lignin reactivity and thus determine the lignin bioconversion performance. To improve the fractionation and bioconversion efficiency of lignin, combinatorial pretreatment was developed (Table 1). Combinatorial pretreatment with a low holding temperature has been confirmed to be a potential technology to maximize the output of fermentable sugars and lignin as well as improve lignin reactivity [38]. It avoids the disadvantages of each single pretreatment by reducing sugar degradation, inhibitor generation, and the need for energy consumption.

To evaluate the lignin reactivity from each pretreatment, lignin (lignins 1-5 as labeled by its corresponding pretreatment Cases: 1-5) was used as the carbon source to produce lipids (Fig. 6). Compared to that from lignin 1 , the cell dry weight from lignins $2-5$ increased by 2.5 to $10.6 \%$ using $R$. opacus PD630 (Fig. 6a1). Using engineered $R$. opacus PD630_FA, the cell dry weight from lignins 2,4 , and 5 was approximated compared to that from lignin 1, but the cell dry weight from lignin 3 was 9.1\% higher than that from lignin 1 (Fig. 6a2). Lignins 2-5 increased the lipid concentration by $6.5-34.8 \%$ compared to lignin 1 . Lignin 4 produced the highest lipid concentration $(0.4 \mathrm{~g} / \mathrm{l})$ among these lignin substrates (Fig. 6a1). The lipid concentration produced from lignins $2-5$ using engineered $R$. opacus PD630_FA increased by $8.8-55.3 \%$ compared with that produced from lignin 1. Lignin 3 produced the highest lignin concentration $(0.53 \mathrm{~g} / \mathrm{l})$ (Fig. 6a2). All of these results implied that lignins 2-5, produced from combinatorial pretreatment, noticeably increased the lipid concentration.

Figure 6b1 shows that the lipid content from lignins 2-5 using $R$. opacus PD630 was 13.2-40.3\% higher than that from lignin 1 . The highest lignin content was 0.17 $\mathrm{g} / \mathrm{l}$ dried cell produced from lignin 4 . Using engineered $R$. opacus PD630_FA, the lipid content in dried cell produced from lignins $2-5$ was $11.8-42.3 \%$ higher than that from lignin 1 . The highest lignin content was $0.20-$ $\mathrm{g} / \mathrm{l}$ dried cell produced from lignin 3 (Fig. 6b2). Notably, engineered $R$. opacus PD630_FA had a 2.5-42.9\% higher lipid content produced from lignins $1-5$ than produce by $R$. opacus PD630. These results suggested that engineered $R$. opacus PD630_FA cells accumulated more lipid. The lipid yield produced from lignins 2 and 4 using $R$. opacus PD630 was $12.0-15.2 \%$ higher than that produced from lignin 1 . The highest lipid yield $(0.16 \mathrm{~g} / \mathrm{g}$ lignin) was for that produced from lignin 4 (Fig. 61). Using engineered $R$. opacus PD630_FA, the lipid yield from lignins $2-5$ was $9.5-24.5 \%$ higher than that from lignin 1 , while the highest lipid yield (0.17-g/l lignin) was that produced from lignin 3 (Fig. 6b2). Notably, the lipid yield from lignins 4-5 using engineered $R$. opacus PD630_FA was $4.8-20.9 \%$ higher than that produced using $R$. opacus PD630. Lignin consumption during lipid fermentation was determined (Fig. 6c). The lignin weight loss was $36.0-42.2 \%$ for lignins $1-5$ using $R$. opacus PD630, while it was $32.8-49.3 \%$ using engineered $R$. opacus PD630_FA. The glucose concentration in the lignin stream produced from each pretreatment was less than $2.3 \mathrm{~g} / \mathrm{l}$, which is much lower than the lignin concentration (Additional file 1). After fermentation, approximately $0.2-1.2-\mathrm{g} / \mathrm{l}$ glucose was consumed in lipid fermentation. The results also showed that the lignin and glucose in the liquid stream of the pretreatment were slightly different among these pretreatments, probably due to the difference in the pretreatment conditions [13, 51]. All of these results supported the results of the cell dry weight and lipid yield. All of the aforementioned results highlighted that the lipid production significantly depends on the types and reactivity of the lignin substrates. Lignin produced from combinatorial pretreatment, especially Cases 3 and 4, resulted in a higher lipid concentration, content, and yield compared to pretreatment Case 1 and thus improved the lipid fermentation performance.

To increase the lipid concentration, fermentation was conducted at a high SSC (30 g/l) using engineered R. opacus PD630_FA (Fig. 7). Compared to that produced from lignin 1, the cell dry weight produced from lignins 2 and 4 increased by 8.7 and $9.5 \%$, respectively, while it decreased by 24.4 and $17.2 \%$ from lignins 3 and 5 (Fig. 7a). However, the lipid concentration produced from lignins $2,3,4$, and 5 was $12.8,76.6,23.9$, and $75.6 \%$ higher than that produced from lignin 1 , respectively. The highest lipid concentration $(0.72 \mathrm{~g} / \mathrm{l})$ was produced from lignins 3 and 5 . Compared to that at $15-\mathrm{g} / \mathrm{l} \mathrm{SSC}$, the lipid concentration at $30-\mathrm{g} / \mathrm{l} \mathrm{SSC}$ increased by $20.6-80.0 \%$ from lignins $1-5$. These results suggested that fermentation at a high SSC produced a high lipid concentration. The lipid contents in dried cell from lignins 2 and 4 were 3.3 and 5.2\%, respectively, which were higher than that from lignin 1 . Interestingly, the lipid contents were 0.26 - and $0.24-\mathrm{g} / \mathrm{g}$ dried cell from lignins 3 and 5 , respectively, which were 2.3 and 2.1 times greater than that from lignin 1. A possible reason for this result could be that during the conditioning of the lignin stream, rotary evaporation of the lignin stream in Cases 3 and 5 was conducted to recover ethanol. Volatile inhibitors may be concomitantly removed, which should facilitate lipid fermentation at a high SSC. The lipid yield from lignins 2 and 3 increased by 18.4 and $26.7 \%$ compared to that from lignin 1 . From lignins 4 and 

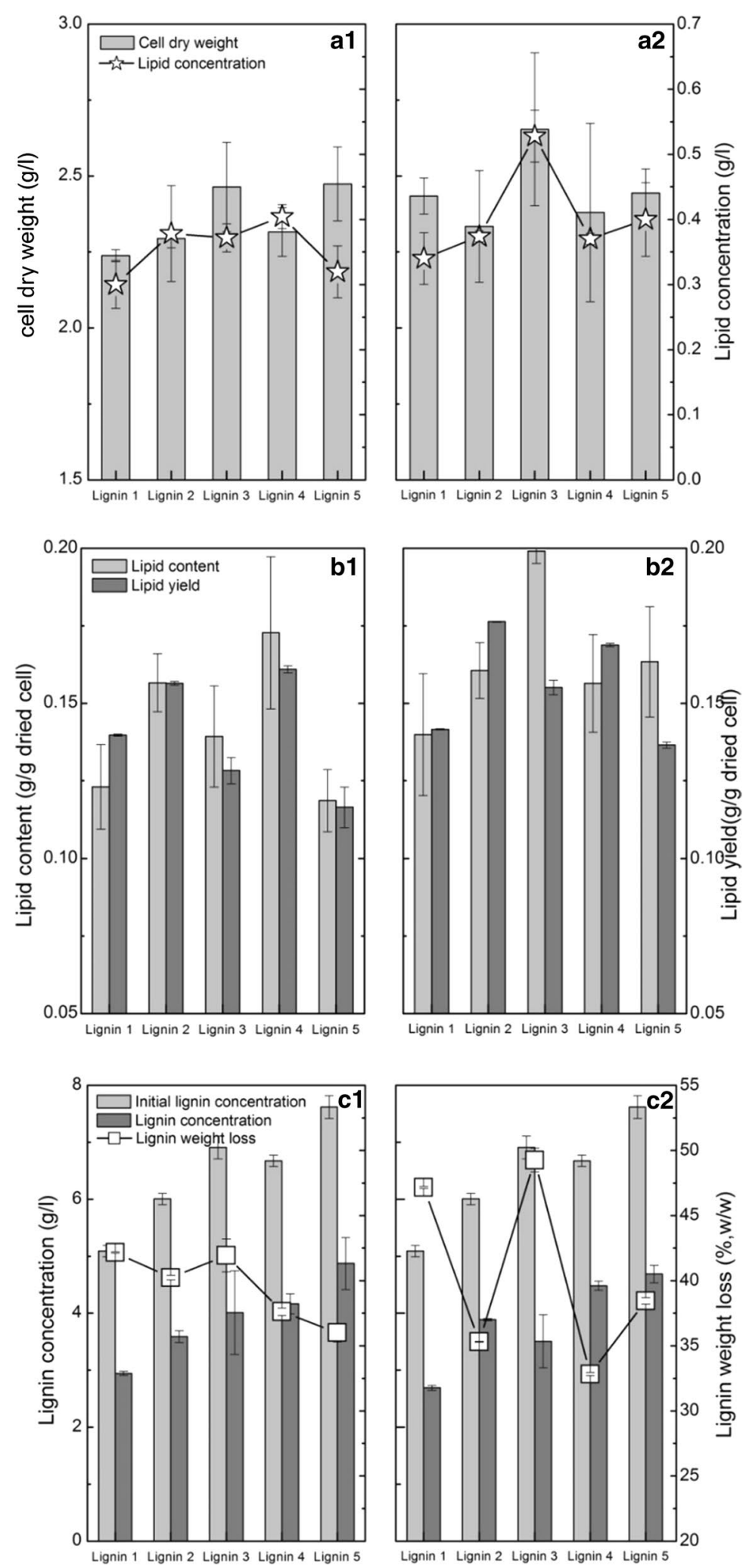

Fig. 6 Lipid fermentation performance of lignin produced by combinatorial pretreatment using R. opacus PD630 (a1, b1, and c1) and engineered R. opacus PD630_FA (a2, b2, c2). Fermentation conditions: 15-g/l soluble substrate concentration, OD 1.0, 1.4-g/l $\left(\mathrm{NH}_{4}\right) \mathrm{SO}_{4}, \mathrm{pH}^{7.0,} 30^{\circ} \mathrm{C}, 200 \mathrm{rpm}$, and 96 h. Lignin 1 lignin sample produced from pretreatment Case 1, as described in Table 1 

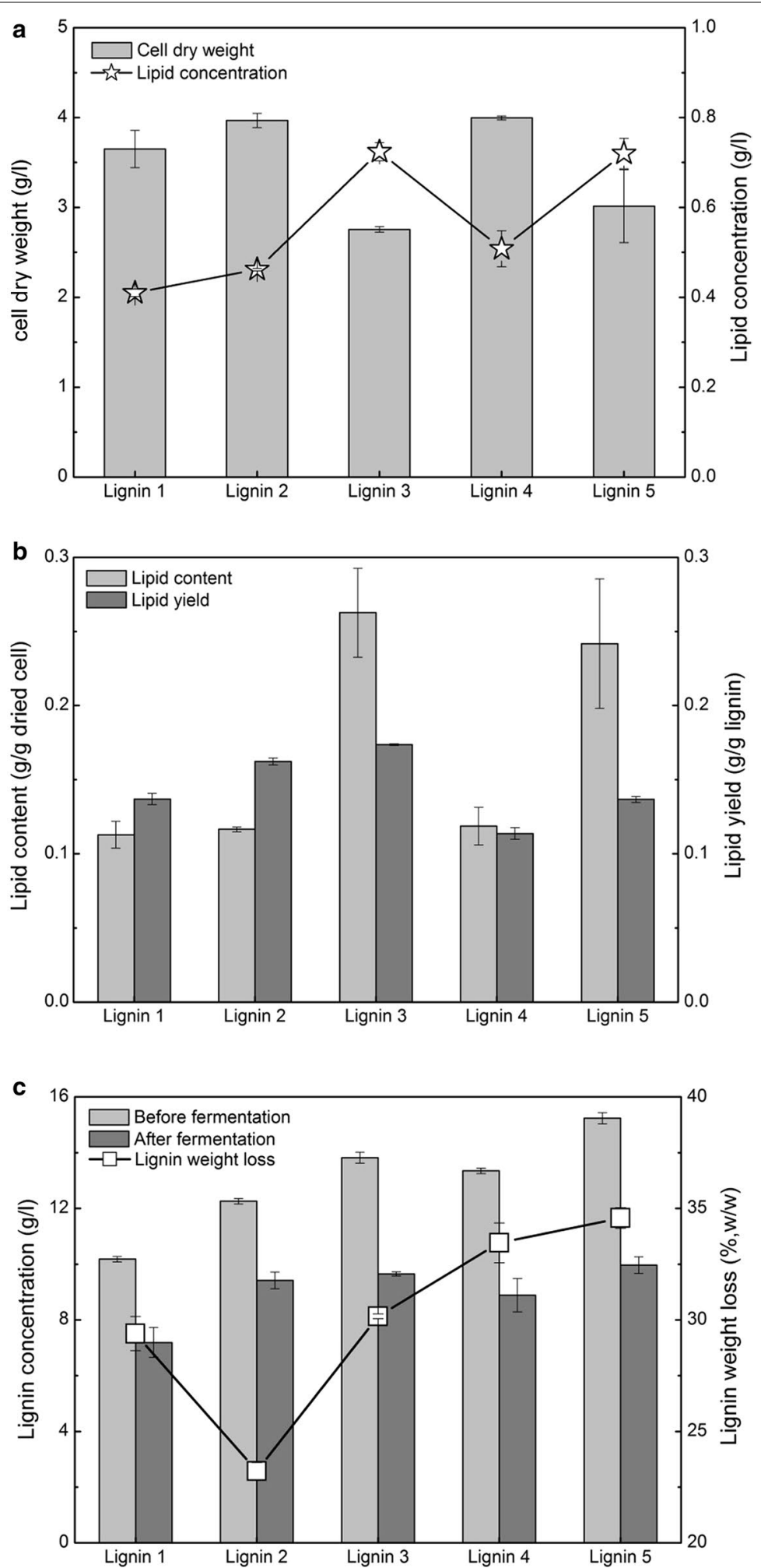

Fig. 7 Lipid fermentation performance at high lignin concentration produced from combinatorial pretreatment by engineered R. opacus PD630_ FA. a cell dry weight and lipid concentration. b lipid content and yield. c lignin concentration and weight loss. Fermentation conditions: $30-\mathrm{g} / \mathrm{l}$ soluble substrate concentration, $\mathrm{OD} 1.0,1.4-\mathrm{g} / \mathrm{l}\left(\mathrm{NH}_{4}\right)_{2} \mathrm{SO}_{4}, \mathrm{pH} 7.0,30^{\circ} \mathrm{C}, 200 \mathrm{rpm}$, and $96 \mathrm{~h}$. Lignin 1 lignin sample produced from pretreatment Case 1 , as described in Table 1 
5, the lipid yield was approximated equivalent to that from lignin 1. Lignin weight loss from lignins 3 , 4, and 5 was higher than that from lignin 1 at $30-\mathrm{g} / \mathrm{l} \mathrm{SSC}$, which supported the above lipid fermentation results well. All of the aforementioned results showed how lignins 2 and 4 increased the cell dry weight compared to lignin 1. Lignins 3 and 5 obviously increased the lipid concentration and content at a high SSC. These results showed that the lipid fermentation performance significantly depended on the reactivity of lignin produced from different fractionation methods.

Aromatic monomers in the lignin medium prepared from each pretreatment were analyzed using GC-MS (Fig. 8). The results showed that the relative abundance of the aromatic monomers depended on the pretreatment options. In general, aromatic monomers are more easily utilized by lignin-degradable microorganisms, especially compared with a lignin polymer. Combinatorial pretreatment Cases 2-5 produced more aromatic monomers than pretreatment Case 1 and thus improved lignin bioconversion. Compared with that using $\mathrm{NaOH}$ (Cases 2 and 4) in Step 2, pretreatment using ethanol $/ \mathrm{NaOH}$ (Cases 3 and 5) produced higher relative abundances of aromatic monomers, which should be helpful in increasing lipid fermentation. This result was consistent with the lipid fermentation results. By the end of lipid fermentation, the aromatic monomers, including 4-hydroxybenzoic acid, vanillic acid, coumarone, benzeneacetic acid, 4-hydroxybenzeneacetic acid, 4-vinylguaiacol, and $p$-coumaric acid, almost disappeared. These aromatic monomers contained a $\mathrm{COOH}$ group and were derived from $p$-coumaryl alcohol $(\mathrm{H})$ and coniferyl alcohol $(\mathrm{G})$ units. $\mathrm{H}$ - or G-type lignins were more likely to be consumed by lignin-degradable bacteria $[47,51]$. A previous study also showed that the major aromatic compounds, such as vanillin, 2,3-dihydro-benzofuran, and 2,3-dimethoxybenzoic acid, disappeared after $168 \mathrm{~h}$ of fermentation by $R$. opacus PD630. Overall, compared to pretreatment Case 1 , combinatorial pretreatment Cases $2-5$ produced more aromatic monomers that were easily consumed, which contributed to the improvement of lipid fermentation.

\section{Detoxification of the lignin stream enhanced lipid fermentation at a high SSC}

Lignin streams produced from different pretreatments contain considerable amounts of degradation compounds. Previous reports have stated that degradation compounds have different inhibition effects on oleaginous strain growth and the product yield, which depend on the type of degradation compounds and oleaginous strains that are used [52, 53]. Before fermentation, detoxification of the liquid streams is required to remove the inhibitors that were formed in pretreatment. The effects of the detoxification methods, including heating $(\mathrm{H})$, activated carbon (AC), and gas stripping $(\mathrm{G})$, were evaluated (Fig. 9). Figure 9a, b shows that activated carbon detoxification removed 22.1 and $17.8 \%$ of the SSC for lignin 1 - AC and lignin 4-AC and 15.4 and $15.2 \%$ of the lignin derivatives for lignin 1-AC and lignin 4-AC, respectively. These results are likely due to the physical adsorption effects of the soluble substrate and lignin derivatives on activated carbon. Heating detoxification removed 1.0$5.0 \%$ of the SSC and $1.0-6.0 \%$ of the lignin derivatives for lignins $1-\mathrm{H}, 2-\mathrm{H}$, and $4-\mathrm{H}$, while gas stripping detoxification removed only $0.76 \%$ of the SSC and $0.38 \%$ of the lignin derivatives for lignin 4-G. These results suggested that the different detoxification strategies have various impacts on the SSC and lignin derivative concentration.

After detoxification, the cell dry weight produced from lignin 1-AC and lignin 4-H was higher than that without detoxification. The cell dry weight produced from lignin 1-H, lignin 2-H, lignin 4-G, and lignin 4-AC was lower than that without detoxification (Figs. 7a, 9c). The possible reason for these results, although detoxification removed most of the inhibitors, is that detoxification may have reduced the concentration of aromatic monomers and low molecular weight lignin derivatives, which are easily utilized. However, lignin $1-\mathrm{H}$, lignin $2-\mathrm{H}$, and lignin $4-\mathrm{H}$ increased the lipid concentration by $7.3,2.9$, and $9.7 \%$, respectively, compared to those without detoxification (Fig. 9c). Lignin 1-AC and lignin 4-G showed a similar lipid concentration to those without detoxification.

After detoxification, the lipid contents produced from lignin 1- $\mathrm{H}$, lignin $2-\mathrm{H}$, lignin $4-\mathrm{H}$, and lignin $4-\mathrm{G}$ increased by $21.0,19.0,15.4$, and $14.2 \%$, respectively, compared to those without detoxification. The lipid yields from lignin $1-\mathrm{H}$, lignin $1-\mathrm{AC}$, lignin $4-\mathrm{H}$, lignin $4-\mathrm{G}$, and lignin $4-\mathrm{AC}$ increased by $19.3,12.2,16.8,5.0$, and $46.2 \%$, respectively, compared to those without detoxification. The results suggested that detoxification of the lignin stream increased the lipid content and lipid yield. A possible reason for this increase is that detoxification may remove the inhibitors as well as facilitate strain growth and thus increase lipid accumulation in cells. All of these results highlighted that detoxification of the lignin stream was an effective strategy to improve the lipid fermentation performance.

\section{Scale-up lipid fermentation at a high soluble substrate concentration}

Scale-up lipid fermentation, using lignin as a carbon source, was carried out in a 2.0-1 fermenter (Table 3 and Fig. 10). Compared to that from lignin 1 at $10 \mathrm{-g} / \mathrm{l}$ SSC with OD1.0 (No. 1 in Table 3), the cell dry weight and lipid concentration from lignin 4 increased by 47 and 14\% (No. 4 in Table 3), respectively (Fig. 10a). The 


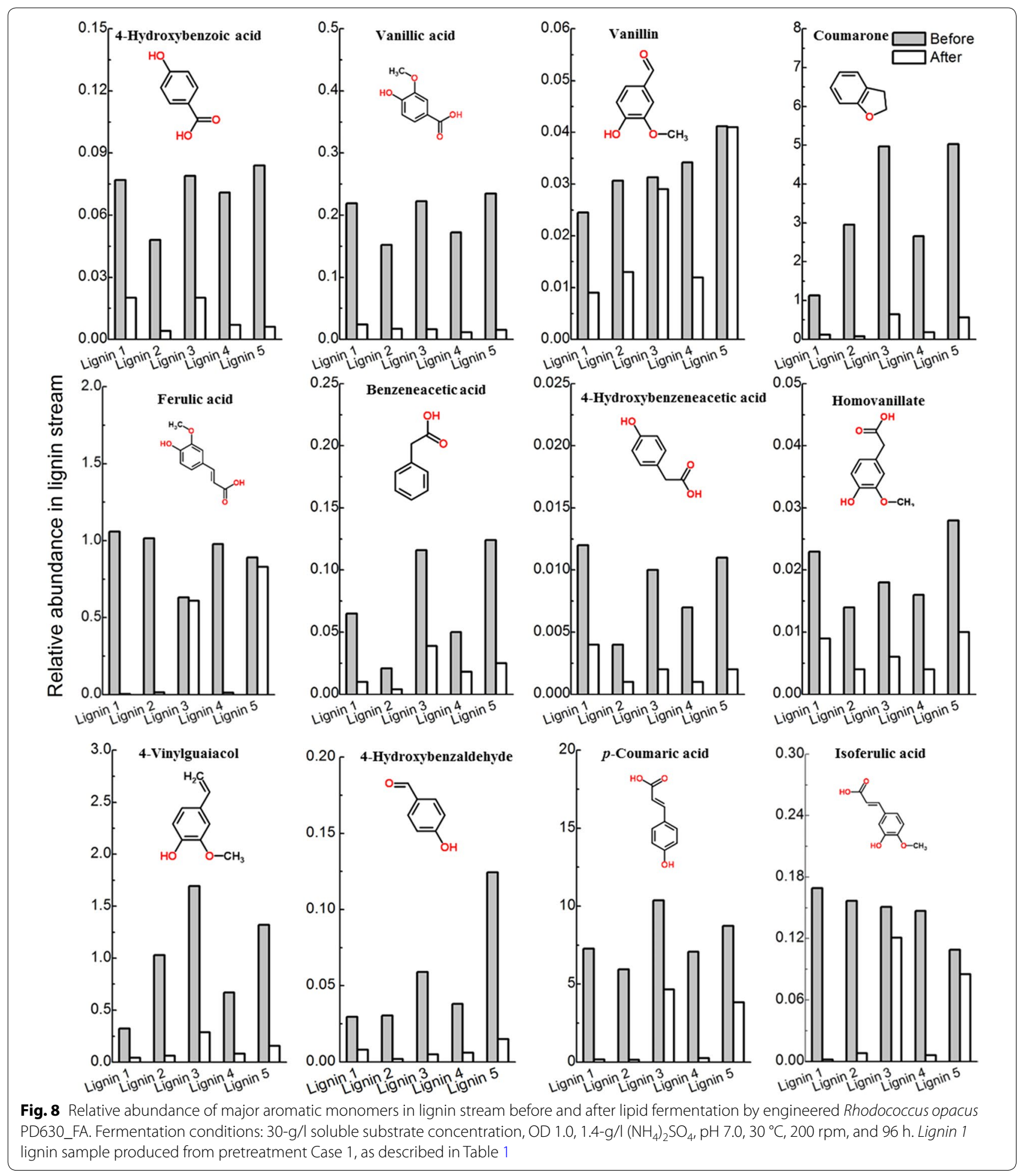

results suggested that combinatorial pretreatment Case 4 improved the scale-up lipid fermentation, which was consistent with the above results. To increase the lipid concentration, a total SSC of $40 \mathrm{~g} / \mathrm{l}$, with a high inoculation
OD, was used in batch and fed-batch fermentation. As shown in Fig. 10a, although an inoculum OD10 was used (No. 2 in Table 3), the cell dry weight and lipid concentration from lignin 1 at $40-\mathrm{g} / \mathrm{l} \mathrm{SSC}$ were only 1.7 and 1.9 

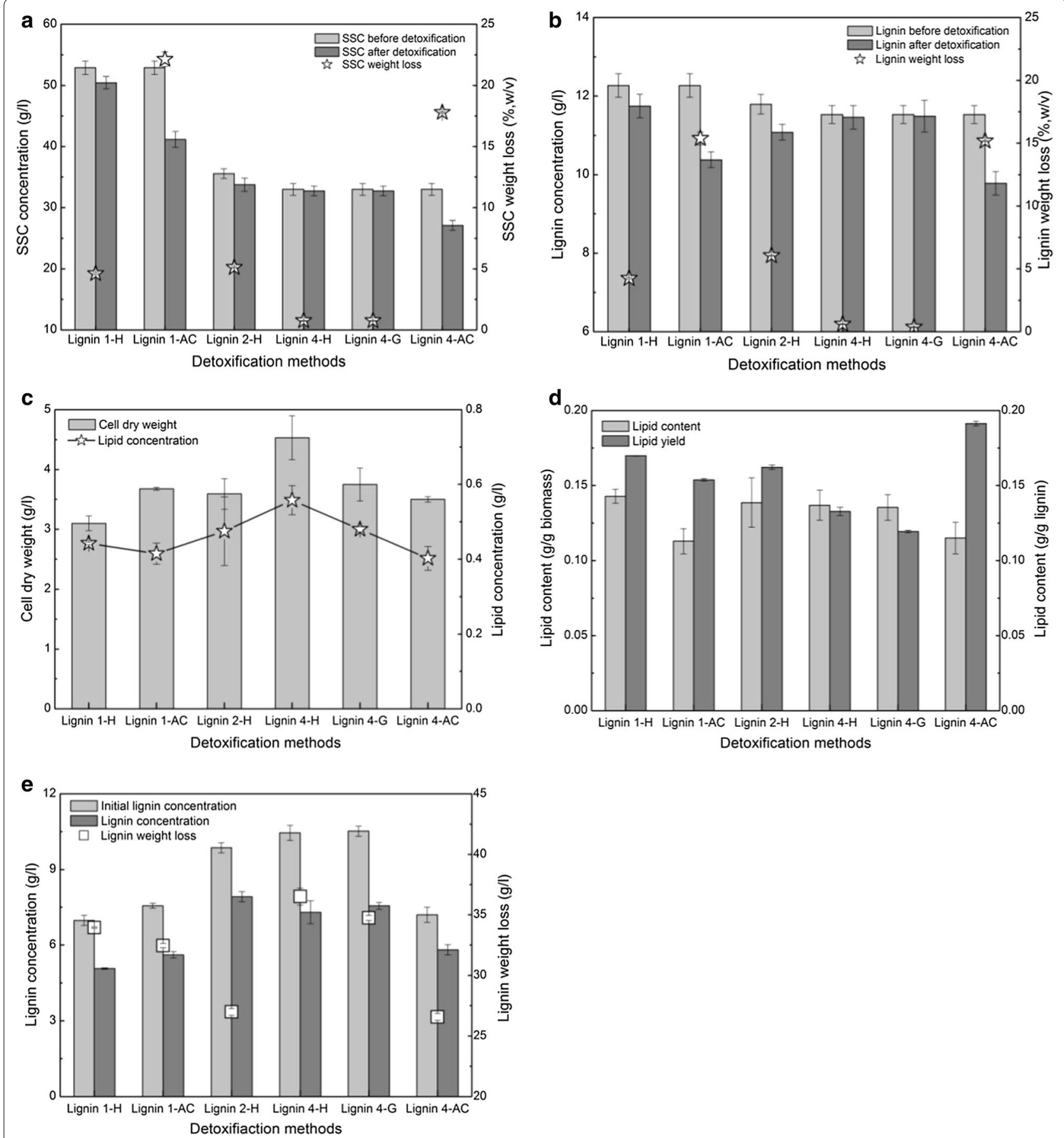

Fig. 9 Lipid fermentation performance of lignin by engineered R. opacus PD630_FA with different detoxification methods. a SSC concentration and weight loss before and after detoxification. b lignin concentration and weight loss before and after detoxification; c cell dry weight and lipid concentration. $\mathbf{d}$ lipid content and yield. e lignin concentration and weight loss before and after fermentation. Fermentation conditions: 30-g/l soluble substrate concentration, OD 1.0, 1.4-g/l $\left(\mathrm{NH}_{4}\right)_{2} \mathrm{SO}_{4}, \mathrm{pH} 7.0,30^{\circ} \mathrm{C}, 200 \mathrm{rpm}$, and $96 \mathrm{~h}$. Lignin 1-H lignin 1 with heating detoxification, Lignin 1-AC lignin 1 with activated carbon detoxification, lignin 4-G lignin 4 with gas stripping detoxification, and Lignin 1 lignin sample produced from pretreatment Case 1, as described in Table 1

times greater than those at 10-g/l SSC with OD1.0 (No. 1 in Table 3). Fed-batch fermentation was conducted at a total SSC of $40 \mathrm{~g} / \mathrm{l}$ with an inoculum OD10 (No. 3 in
Table 3), from which the cell dry weight and lipid concentration were 1.7 and 1.5 times greater than those of batch fermentation (No. 2 in Table 3), respectively. These 

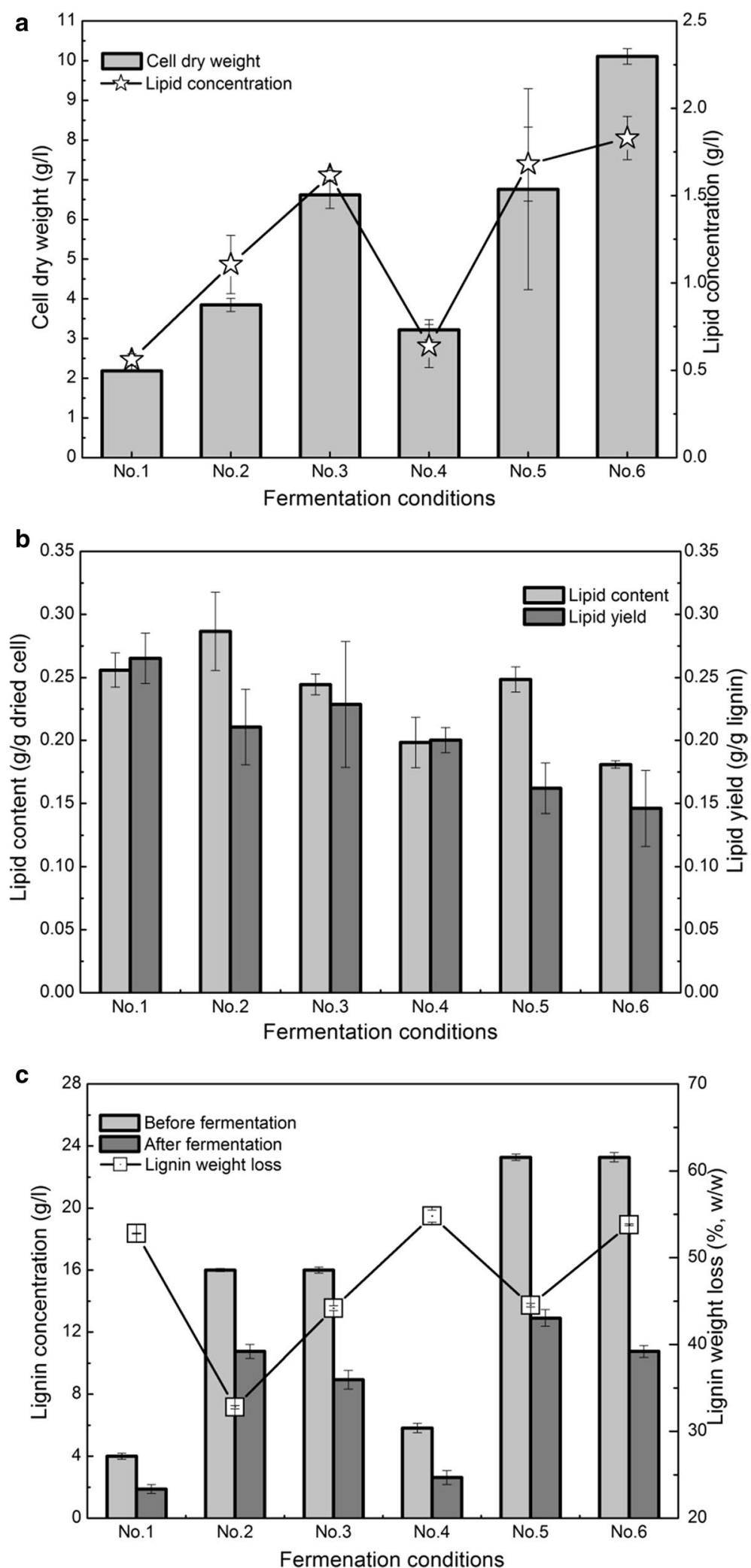

Fig. 10 Lipid fermentation performance of lignin with batch or fed-batch fermentation using engineered R. opacus PD630_FA in 2.0-I fermenter. a cell dry weight and lipid concentration. b lipid content and yield. c lignin concentration and weight loss. Fermentation conditions: $\mathrm{pH}^{7.0,60 \% ~} \mathrm{pO}_{2}$ $30^{\circ} \mathrm{C}$, and $200 \mathrm{rpm}$. Nos. 1-6 represents the fermentation strategies, as shown in Table 3 
results indicated that fed-batch fermentation increased the lipid fermentation performance of lignin 1.

Using lignin 4 as a carbon source (No. 5 in Table 3), the cell dry weight and lipid concentration with an inoculum at OD5.0 were 1.8 and 1.5 times greater than those from lignin 1 at OD10 (No. 2 in Table 3), respectively. Although an inoculum at OD5.0 was used in fed-batch fermentation (No. 5 in Table 3), the cell dry weight and lipid concentration from lignin 4 were higher than those from lignin 1 (No. 3 in Table 3). Laccase treatment was then used to depolymerize lignin to improve the lipid fermentation performance. As shown in Fig. 10a (No. 6 in Table 3), the highest cell dry weight and lipid concentration were 10.1 and $1.83 \mathrm{~g} / \mathrm{l}$, respectively, which were produced from lignin 4 with laccase treatment. The cell dry weight and lipid concentration in No. 6 were 1.5 and 1.2 times greater than those in No. 3 and 1.4 and 1.1 times greater than those in No. 5, respectively. These results suggested that laccase treatment of the lignin stream obviously improved the lipid fermentation performance, which may be due to the decreased molecular weight of lignin and increased lignin reactivity. Zhao et al. also reported that $R$. opacus cell growth increased exponentially in response to the level of laccase treatment of lignin [27]. The results showed that the cell dry weight and lipid concentration in a fermenter were higher than those in a flask, because the fermenter can provide adequate oxygen and control the $\mathrm{pH}$ of the medium accurately. A previous study also reported that a fed-batch culture in a stirred-tank fermenter produced a higher cell biomass, lipid content, and lipid productivity rate than that in a shaking flask [48]. Fed-batch fermentation of lignin 4 (Nos. 5 and 6 in Table 3) led to a lower lipid content and yield compared to those of lignin 1 . It should be noted that a higher inoculum OD was used in Nos. 2 and 3 , thereby contributing to the increased lipid content and yield. Overall, these results highlighted that combinatorial pretreatment integrated with fed-batch fermentation increased the lipid fermentation performance during scale-up fermentation.

\section{Conclusions}

Combinatorial pretreatment was developed to fractionate lignin from corn stover, improve lignin reactivity, and ultimately, enhance lipid production. Combinatorialpretreated lignins 2-5 increased the lipid concentration by $12.8-75.6 \%$ at $30-\mathrm{g} / 1$ SSC compared to single-pretreated lignin 1 . The highest cell dry weight and lipid concentration in the fermenter were 10.1 and $1.83 \mathrm{~g} / \mathrm{l}$, respectively, which were produced from combinatorialpretreated lignin 4 , followed by laccase treatment in fedbatch fermentation. These results demonstrated that the lipid fermentation performance using lignin as a carbon source can be favorably improved by a combinatorial pretreatment with optimization of varying fermentation conditions.

\section{Additional file}

Additional file 1. Additional table and figure.

\section{Abbreviations}

AC: activated carbon; C: carbon source; CDW: cell dry weight; EOL: ethanol organosolv lignin; GC-MS: gas chromatography-mass spectrometry; GS: gas stripping; $\mathrm{H}$ : heating; $\mathrm{N}$ : nitrogen source; SSC: soluble substrate concentration; TSB: Tryptic Soy Broth.

\section{Authors' contributions}

ZHL and JSY participated in the design of the study. ZHL performed the statistical analysis and drafted the manuscript. SXX and FRL participated in conducting the fermentation experiment. JSY and MJJ revised the manuscript. All authors read and approved the final manuscript.

\section{Author details}

1 Synthetic and Systems Biology Innovation Hub (SSBiH), Texas A\&M University, College Station, TX 77843, USA. ${ }^{2}$ Department of Plant Pathology and Microbiology, Texas A\&M University, College Station, TX 77843, USA. ${ }^{3}$ Institute for Plant Genomics and Biotechnology, Texas A\&M University, College Station, TX 77843, USA. ${ }^{4}$ School of Environmental and Biological Engineering, Nanjing University of Science and Technology, Nanjing 210094, China. ${ }^{5}$ Guangdong Cleamol LTD, Foshan 528225, China.

\section{Acknowledgements}

The work was financially supported by the US DOE (Department of Energy) EERE (Energy Efficiency and Renewable Energy) BETO (Bioenergy Technology Office) (Grant No. DE-EE0006112).

\section{Competing interests}

The authors declare that they have no competing interests.

\section{Ethics approval and consent to participate}

Not applicable.

\section{Publisher's Note}

Springer Nature remains neutral with regard to jurisdictional claims in published maps and institutional affiliations.

Received: 30 September 2017 Accepted: 11 January 2018

Published online: 29 January 2018

References

1. Himmel ME, Ding S-Y, Johnson DK, Adney WS, Nimlos MR, Brady JW, Foust TD. Biomass recalcitrance: engineering plants and enzymes for biofuels production. Science. 2007;315(5813):804-7.

2. Ragauskas AJ, Beckham GT, Biddy MJ, Chandra R, Chen F, Davis MF, Davison BH, Dixon RA, Gilna P, Keller M. Lignin valorization: improving lignin processing in the biorefinery. Science. 2014;344(6185):1246843.

3. Lau MW, Dale BE. Cellulosic ethanol production from AFEX-treated corn stover using Saccharomyces cerevisiae 424A(LNH-ST). Proc Natl Acad Sci USA. 2009;106(5):1368-73.

4. Liu ZG, Liao W, Liu Y. A sustainable biorefinery to convert agricultural residues into value-added chemicals. Biotechnol Biofuels. 2016;9:197.

5. Zakzeski J, Bruijnincx PC, Jongerius AL, Weckhuysen BM. The catalytic valorization of lignin for the production of renewable chemicals. Chem Rev. 2010;110(6):3552-99.

6. Chen Z, Wan C. Biological valorization strategies for converting lignin into fuels and chemicals. Renew Sustain Energy Rev. 2017;73:610-21. 
7. Bugg TD, Rahmanpour R. Enzymatic conversion of lignin into renewable chemicals. Curr Opin Chem Biol. 2015;29:10-7.

8. Xie S, Qin X, Cheng Y, Laskar D, Qiao W, Sun S, Reyes LH, Wang X, Dai SY, Sattler SE. Simultaneous conversion of all cell wall components by an oleaginous fungus without chemi-physical pretreatment. Green Chem. 2015;17(3):1657-67.

9. Yang $S$, Zhang Y, Yue W, Wang W, Wang YY, Yuan TQ, Sun RC. Valorization of lignin and cellulose in acid-steam-exploded corn stover by a moderate alkaline ethanol post-treatment based on an integrated biorefinery concept. Biotechnol Biofuels. 2016;9:238.

10. Kim JS, Lee YY, Kim TH. A review on alkaline pretreatment technology for bioconversion of lignocellulosic biomass. Bioresour Technol. 2016;199:42-8.

11. Isikgor FH, Becer CR. Lignocellulosic biomass: a sustainable platform for the production of bio-based chemicals and polymers. Polym Chem-Uk. 2015;6(25):4497-559.

12. Beckham GT, Johnson CW, Karp EM, Salvachúa D, Vardon DR. Opportunities and challenges in biological lignin valorization. Curr Opin Biotechnol. 2016;42:40-53.

13. Linger JG, Vardon DR, Guarnieri MT, Karp EM, Hunsinger GB, Franden MA, Johnson CW, Chupka G, Strathmann TJ, Pienkos PT. Lignin valorization through integrated biological funneling and chemical catalysis. Proc Natl Acad Sci. 2014;111(33):12013-8.

14. Wyman CE, Ragauskas AJ. Lignin bioproducts to enable biofuels. Biofuels Bioprod Biorefin. 2015;9(5):447-9.

15. Xie S, Ragauskas AJ, Yuan JS. Lignin conversion: opportunities and challenges for the integrated biorefinery. Ind Biotechnol. 2016;12(3):161-7.

16. Chen HZ, Liu ZH. Multilevel composition fractionation process for highvalue utilization of wheat straw cellulose. Biotechnol Biofuels. 2014;7:137.

17. Li YH, Zhao ZB, Bai FW. High-density cultivation of oleaginous yeast Rhodosporidium toruloides $Y 4$ in fed-batch culture. Enzyme Microb Tech. 2007:41(3):312-7.

18. Xu X, Kim JY, Cho HU, Park HR, Park JM. Bioconversion of volatile fatty acids from macroalgae fermentation into microbial lipids by oleaginous yeast. Chem Eng J. 2015;264:735-43.

19. Wei Z, Zeng G, Huang F, Kosa M, Huang D, Ragauskas AJ. Bioconversion of oxygen-pretreated Kraft lignin to microbial lipid with oleaginous Rhodococcus opacus DSM 1069. Green Chem. 2015;17(5):2784-9.

20. Patel A, Arora N, Pruthi V, Pruthi PA. Biological treatment of pulp and paper industry effluent by oleaginous yeast integrated with production of biodiesel as sustainable transportation fuel. J Clean Prod. 2017;142:2858-64.

21. Leiva-Candia DE, Pinzi S, Redel-Macías MD, Koutinas A, Webb C, Dorado MP. The potential for agro-industrial waste utilization using oleaginous yeast for the production of biodiesel. Fuel. 2014;123(Supplement C):33-42.

22. Lin L, Cheng Y, Pu Y, Sun S, Li X, Jin M, Pierson EA, Gross DC, Dale BE, Dai SY, et al. Systems biology-guided biodesign of consolidated lignin conversion. Green Chem. 2016;18(20):5536-47.

23. Le RK, Wells T, Das P, Meng XZ, Stoklosa RJ, Bhalla A, Hodge DB, Yuan JS, Ragauskas AJ. Conversion of corn stover alkaline pre-treatment waste streams into biodiesel via Rhodococci. Rsc Adv. 2017;7(7):4108-15.

24. Benocci T, Aguilar-Pontes MV, Zhou M, Seiboth B, de Vries RP. Regulators of plant biomass degradation in ascomycetous fungi. Biotechnol Biofuels. 2017;10:152.

25. Wells T, Ragauskas AJ. Biotechnological opportunities with the betaketoadipate pathway. Trends Biotechnol. 2012;30(12):627-37.

26. Varman AM, He L, Follenfant R, Wu WH, Wemmer S, Wrobel SA, Tang YJJ, Singh S. Decoding how a soil bacterium extracts building blocks and metabolic energy from ligninolysis provides road map for lignin valorization. Proc Natl Acad Sci USA. 2016;113(40):E5802-11.

27. Zhao C, Xie S, Pu Y, Zhang R, Huang F, Ragauskas AJ, Yuan JS. Synergistic enzymatic and microbial lignin conversion. Green Chem. 2016;18(5):1306-12.

28. Liu ZH, Qin L, Li BZ, Yuan YJ. Physical and chemical characterizations of corn stover from leading pretreatment methods and effects on enzymatic hydrolysis. Acs Sustain Chem Eng. 2015;3(1):140-6.

29. Chen HZ, Liu ZH. Steam explosion and its combinatorial pretreatment refining technology of plant biomass to bio-based products. Biotechnol J. 2015;10(6):866-85.

30. Tian D, Chandra RP, Lee JS, Lu CH, Saddler JN. A comparison of various lignin-extraction methods to enhance the accessibility and ease of enzymatic hydrolysis of the cellulosic component of steam-pretreated poplar. Biotechnol Biofuels. 2017;10:157.
31. Kim KH, Dutta T, Ralph J, Mansfield SD, Simmons BA, Singh S. Impact of lignin polymer backbone esters on ionic liquid pretreatment of poplar. Biotechnol Biofuels. 2017;10:101.

32. Xie S, Syrenne R, Sun S, Yuan JS. Exploration of natural biomass utilization systems (NBUS) for advanced biofuel—from systems biology to synthetic design. Curr Opin Biotechnol. 2014;27:195-203.

33. Lv JM, Cheng LH, Xu XH, Zhang L, Chen HL. Enhanced lipid production of Chlorella vulgaris by adjustment of cultivation conditions. Bioresour Technol. 2010;101(17):6797-804.

34. Economou CN, Aggelis G, Pavlou S, Vayenas DV. Modeling of single-cell oil production under nitrogen-limited and substrate inhibition conditions. Biotechnol Bioeng. 2011;108(5):1049-55.

35. Jonsson LJ, Alriksson B, Nilvebrant NO. Bioconversion of lignocellulose: inhibitors and detoxification. Biotechnol Biofuels. 2013;6:16.

36. Palmqvist $E$, Hahn-Hagerdal B. Fermentation of lignocellulosic hydrolysates. Il: inhibitors and mechanisms of inhibition. Bioresour Technol. 2000;74(1):25-33.

37. Liu ZH, Qin L, Zhu JQ, Li BZ, Yuan YJ. Simultaneous saccharification and fermentation of steam-exploded corn stover at high glucan loading and high temperature. Biotechnol Biofuels. 2014;7:167.

38. Liu ZH, Olson ML, Shinde S, Wang X, Hao NJ, Yoo CG, Bhagia S, Dunlap JR, $\mathrm{Pu} Y \mathrm{YQ}$, Kao KC, et al. Synergistic maximization of the carbohydrate output and lignin processability by combinatorial pretreatment. Green Chem. 2017;19(20):4939-55

39. Rakicka M, Lazar Z, Dulermo T, Fickers P, Nicaud JM. Lipid production by the oleaginous yeast Yarrowia lipolytica using industrial by-products under different culture conditions. Biotechnol Biofuels. 2015;8:104.

40. Ghidossi T, Marison I, Devery R, Gaffney D, Forde C. Characterization and optimization of a fermentation process for the production of high cell densities and lipids using heterotrophic cultivation of chlorella protothecoides. Ind Biotechnol. 2017;13(5):253-9.

41. Kosa M, Ragauskas AJ. Lignin to lipid bioconversion by oleaginous Rhodococci. Green Chem. 2013;15(8):2070-4.

42. Wu SG, Zhao X, Shen HW, Wang QA, Zhao ZBK. Microbial lipid production by Rhodosporidium toruloides under sulfate-limited conditions. Bioresour Technol. 2011;102(2):1803-7.

43. Sestric R, Munch G, Cicek N, Sparling R, Levin DB. Growth and neutral lipid synthesis by Yarrowia lipolytica on various carbon substrates under nutrient-sufficient and nutrient-limited conditions. Bioresour Technol. 2014;164:41-6

44. Singhasuwan S, Choorit W, Sirisansaneeyakul S, Kokkaew N, Chisti Y. Carbon-to-nitrogen ratio affects the biomass composition and the fatty acid profile of heterotrophically grown Chlorella sp. TISTR 8990 for biodiesel production. J Biotechnol. 2015;216:169-77.

45. Liu TT, LiYQ Liu F. Wang C. The enhanced lipid accumulation in oleaginous microalga by the potential continuous nitrogen-limitation (CNL) strategy. Bioresour Technol. 2016;203:150-9.

46. Poli JS, da Silva MAN, Siqueira EP, Pasa VMD, Rosa CA, Valente P. Microbial lipid produced by Yarrowia lipolytica QU21 using industrial waste: a potential feedstock for biodiesel production. Bioresour Technol. 2014;161:320-6.

47. Kosa M, Ragauskas AJ. Bioconversion of lignin model compounds with oleaginous Rhodococci. Appl Microbiol Biotechnol. 2012;93(2):891-900.

48. Zhang J, Fang X, Zhu XL, Li Y, Xu HP, Zhao BF, Chen L, Zhang XD. Microbial lipid production by the oleaginous yeast Cryptococcus curvatus $\mathrm{O} 3$ grown in fed-batch culture. Biomass Bioenerg. 2011:35(5):1906-11.

49. Liu ZH, Chen HZ. Periodic peristalsis enhancing the high solids enzymatic hydrolysis performance of steam exploded corn stover biomass. Biomass Bioenerg. 2016;93:13-24.

50. Cannella D, Jorgensen H. Do new cellulolytic enzyme preparations affect the industrial strategies for high solids lignocellulosic ethanol production? Biotechnol Bioeng. 2014;111(1):59-68.

51. He Y, Li X, Ben H, Xue X, Yang B. Lipid production from dilute alkal corn stover lignin by Rhodococcus strains. Acs Sustain Chem Eng. 2017;5(3):2302-11.

52. Hu CM, Zhao X, Zhao J, Wu SG, Zhao ZBK. Effects of biomass hydrolysis by-products on oleaginous yeast Rhodosporidium toruloides. Bioresour Technol. 2009;100(20):4843-7.

53. Zhao XB, Peng F, Du W, Liu CM, Liu DH. Effects of some inhibitors on the growth and lipid accumulation of oleaginous yeast Rhodosporidium toruloides and preparation of biodiesel by enzymatic transesterification of the lipid. Bioprocess Biosyst Eng. 2012;35(6):993-1004. 